\title{
Hydrate thermal dissociation behavior and dissociation enthalpies in methane-carbon dioxide swapping process
}

\author{
Mu, Liang; von Solms, Nicolas
}

Published in:

Journal of Chemical Thermodynamics

Link to article, DOI:

10.1016/j.jct.2017.08.018

Publication date:

2018

Document Version

Peer reviewed version

Link back to DTU Orbit

Citation (APA):

Mu, L., \& von Solms, N. (2018). Hydrate thermal dissociation behavior and dissociation enthalpies in methanecarbon dioxide swapping process. Journal of Chemical Thermodynamics, 117, 33-42.

https://doi.org/10.1016/j.jct.2017.08.018

\section{General rights}

Copyright and moral rights for the publications made accessible in the public portal are retained by the authors and/or other copyright owners and it is a condition of accessing publications that users recognise and abide by the legal requirements associated with these rights.

- Users may download and print one copy of any publication from the public portal for the purpose of private study or research.

- You may not further distribute the material or use it for any profit-making activity or commercial gain

- You may freely distribute the URL identifying the publication in the public portal

If you believe that this document breaches copyright please contact us providing details, and we will remove access to the work immediately and investigate your claim 
Final accepted manuscript:

$\mathrm{Mu}, \mathrm{L}$., \& von Solms, N. (2018). Hydrate thermal dissociation behavior and dissociation enthalpies in methane-carbon dioxide swapping process. Journal of Chemical Thermodynamics, 117, 33-42. https://doi.org/10.1016/i.jct.2017.08.018

https://doi.org/10.1016/i.enconman.2017.12.079

\title{
Hydrate thermal dissociation behavior and
}

\section{dissociation enthalpies in methane-carbon dioxide}

\section{swapping process}

\author{
Liang Mu and Nicolas von Solms*
}

Department of Chemical and Biochemical Engineering, Center for Energy Resource Engineering (CERE), Technical University of Denmark, DK-2800 Kgs. Lyngby, Denmark

\begin{abstract}
:
The swapping of methane with carbon dioxide in hydrate has been proposed as a potential strategy for geologic sequestration of carbon dioxide and production of methane from natural hydrate deposits. However, this strategy requires a better understanding of the thermodynamic characteristics of $\mathrm{CH}_{4}$ and $\mathrm{CO}_{2}$ hydrate as well as $\left(\mathrm{CH}_{4}+\mathrm{CO}_{2}\right)$ or $\left(\mathrm{CH}_{4}+\mathrm{CO}_{2}+\mathrm{N}_{2}\right)$ mixed hydrates
\end{abstract}


(since $\left(\mathrm{CO}_{2}+\mathrm{N}_{2}\right)$ gas mixture is often used as the swapping gas), along with the thermal physics property changes during gas exchange. In this study, a high pressure micro-differential scanning calorimetry (HP $\mu$-DSC) was performed on synthesized gas hydrates to investigate the dissociation behavior of various hydrates. The hydrate dissociation enthalpies were determined by both $\mu$-DSC measurement and Clapeyron equation. For the single guest molecule hydrate system, the average dissociation enthalpies of $\mathrm{CH}_{4}$ hydrate and $\mathrm{CO}_{2}$ hydrate measured by integrating the endothermic peak area are $55.04 \mathrm{~kJ} \cdot \mathrm{mol}^{-1}$ and $58.95 \mathrm{~kJ} \cdot \mathrm{mol}^{-1}$, respectively, which are very close to the values calculated by Clapeyron equation. However, in the multicomponent guest hydrates system, the $\mu$ DSC measured dissociation enthalpies of the $\left(\mathrm{CH}_{4}+\mathrm{CO}_{2}\right)$ binary hydrates and $\left(\mathrm{CH}_{4}+\mathrm{CO}_{2}+\mathrm{N}_{2}\right)$ ternary hydrates are a little higher than that of Clapeyron equation, it was found that their dissociation enthalpies locate between the limiting values of pure $\mathrm{CH}_{4}$ hydrate and $\mathrm{CO}_{2}$ hydrate, increasing with the mole fraction of $\mathrm{CO}_{2}$ in hydrate phase. By monitoring the heat flow changes with the $\mu$-DSC apparatus, it showed that there was no noticeable dissociation or formation process of hydrate occurring in the $\mathrm{CH}_{4}-\mathrm{CO}_{2} /\left(\mathrm{CO}_{2}+\mathrm{N}_{2}\right)$ swapping, which indicates that most $\mathrm{CH}_{4}$ hydrate forms $\left(\mathrm{CH}_{4}+\mathrm{CO}_{2}\right)$ or $\left(\mathrm{CH}_{4}+\mathrm{CO}_{2}+\mathrm{N}_{2}\right)$ mixed hydrates directly instead of dissociating into liquid water or ice first. The dissociation equilibrium data obtained from the endothermic thermograms of the mixed hydrates after $\mathrm{CO}_{2}$ and $\left(\mathrm{CO}_{2}+\mathrm{N}_{2}\right)$ swapping demonstrates that about $66 \%$ and $85 \%$ of $\mathrm{CH}_{4}$ in hydrate phase are replaced, respectively.

\section{Introduction}

Gas hydrates are ice-like crystalline compounds composed of cages formed by hydrogenbonded water molecules which encapsulate small guest molecules, such as light hydrocarbons and carbon dioxide, under high pressure and low temperature conditions [1]. Depending on the size and 
shape of guest molecules, there are three different structures of clathrate hydrates: structure I (sI), structure II (sII) and structure $\mathrm{H}(\mathrm{sH})$. Gas hydrates are non-stoichiometric compounds and on a mole basis, methane hydrate consists of $85.69( \pm 0.14) \%$ water and $14.31( \pm 0.14) \%$ methane [2]. This results in the physical and thermal properties of hydrates are similar to that of ice with some exceptions. For instance, William et al. [3] found that methane hydrate is over twenty times stronger than ice at the same conditions of temperature and strain rate, and John et al. [4] believed that the thermal conductivity of hydrate is about four times lower than that of ice.

Large quantities of natural gas hydrates, which are primarily composed of $\mathrm{CH}_{4}$, are found in permafrost regions and deep ocean sediments, and they are regarded as a promising energy resource in the future [5-10]. Recent years, the $\mathrm{CH}_{4}-\mathrm{CO}_{2}$ swapping in naturally occurring gas hydrates has been suggested as an attractive method of both $\mathrm{CH}_{4}$ recovery and $\mathrm{CO}_{2}$ sequestration [11-18]. The swapping of $\mathrm{CH}_{4}$ with $\mathrm{CO}_{2}$ from its hydrate phase is a thermodynamically spontaneous reaction [19] and does not accompany the potential geo-mechanical hazards that might occur during hydrate exploitation process [20]. Using swapping technology for the purpose of methane gas recovery and $\mathrm{CO}_{2}$ geologic storage requires a better understanding of the thermodynamic properties of $\mathrm{CH}_{4}$ and $\mathrm{CO}_{2}$ hydrates. The dissociation enthalpy of $\left(\mathrm{CH}_{4}+\mathrm{CO}_{2}\right)$ binary hydrate is a key parameter in predicting the process on a reservoir scale because considerable latent heat might be generated or absorbed in swapping. Some dissociation equilibrium data for gas hydrates have been reported in the literature and are well summarized by Sloan [1]. Kwon et al [21] investigated the thermal dissociation behavior of $\left(\mathrm{CH}_{4}+\mathrm{CO}_{2}\right)$ binary mixed hydrates in a rigid-walled high-pressure reaction vessel. They analyzed the compositions changes in vapor phase and hydrate phase during dissociation based on gas chromatography measurements, calculated the dissociation enthalpy of $\left(\mathrm{CH}_{4}+\mathrm{CO}_{2}\right)$ mixed hydrate by fitting Clausius-Clapeyron equation to the pressure-temperature trace of a dissociation test. Since the classical thermodynamic methods of phase equilibrium require a 
considerable time for accurate experimental results, some researchers explored other measurement techniques. In 1980s, Handa [22-24] measured the compositions, dissociation enthalpies and heat capacities of hydrates of methane, propane, ethane, isobutene and natural gas hydrates over a wide range of temperatures $(85-270 \mathrm{~K})$ using a Calvet calorimeter. Recent years, differential scanning calorimetry (DSC) is broadly used for the characterization of phase change as a rapid and sensitive technique. Some researchers [25-27] compared DSC results of hydrates with phase equilibrium data obtained using a more classical technique, such as measurements of pressure variation vs. temperature at constant volume (PVT), demonstrating the validity of this application. Gupta et al [28] measured methane hydrate dissociation heat from 5.5 to $19.3 \mathrm{MPa}$ using a DSC apparatus. They formed methane hydrate sample ex-situ using granular ice particles and transferred it into the DSC cell under liquid nitrogen, subsequently the sample was dissociated by raising the temperature above the hydrate equilibrium temperature at a constant pressure. They believed that the measured dissociation enthalpy of $\mathrm{CH}_{4}$ hydrate is in agreement with the Clapeyron equation predictions at high pressures, while the Clausius-Clapeyron equation predictions have a high relative error. Lee et al [29] used a high pressure micro-differential scanning calorimeter (HP $\mu$-DSC) to investigate the $\mathrm{CH}_{4}-\mathrm{CO}_{2}$ swapping process. Their hydrate dissociation equilibrium data obtained from the endothermic thermograms of the replaced gas hydrates indicate that at least $60 \%$ of $\mathrm{CH}_{4}$ is recoverable after reaction with $\mathrm{CO}_{2}$.

In this work, the changes of heat flow in various hydrates dissociation process were investigated using a high pressure micro-differential scanning calorimeter apparatus. Our study mainly focus on three points: 1, measure the dissociation enthalpies of various gas hydrates accurately, calculate them directly from the endothermic peak area integration and indirectly using the Clapeyron equation, since there is a significant difference among the published data about that, for instance, the dissociation enthalpy of $\mathrm{CO}_{2}$ hydrate which Kamath [30] measured and reported is $80 \mathrm{~kJ} \cdot \mathrm{mol}^{-1}$, 
while Qazi [31] believed that it is $53.29 \mathrm{~kJ} \cdot \mathrm{mol}^{-1}$; 2, investigate if the $\mathrm{CH}_{4}$ hydrate dissociates while the swapping reaction is proceeding, and reveal the influence of an additional guest on the thermal behavior of the $\mathrm{CH}_{4}$ hydrate, because it is controversial according to the existing literature reports, some researchers believe the $\mathrm{CH}_{4}$ hydrate would dissociate while others insist the hydrate structure would not be destroyed; 3, estimate the extent of $\mathrm{CO}_{2}$ and $\left(\mathrm{CO}_{2}+\mathrm{N}_{2}\right)$ swapping and exploring if all the $\mathrm{CH}_{4}$ molecules can be recovered by swapping technology.

\section{Experimental Section}

\subsection{Materials}

Analytical grade methane (99.99\%), carbon dioxide $(99.99 \%)$, and nitrogen $(99.99 \%)$ were obtained from AGA Gas Company. The gas mixtures were prepared by us and analyzed using a Agilent gas chromatograph (7890 A), the molar composition of each gas mixture is listed in Table 1. Gas mixture $M_{1}$ and $M_{2}$ are used to form binary and ternary hydrates and investigate their dissociation behavior, $\mathrm{M}_{3}$ is used for swapping gas. Deionized water was used in the experiment.

Table 1. The molar compositions (mol\%) of gas mixtures $\mathrm{M}_{1}-\mathrm{M}_{3}$ used in this work.

\begin{tabular}{cccc}
\hline Component & $\mathrm{M}_{1}$ & $\mathrm{M}_{2}$ & $\mathrm{M}_{3}$ \\
\hline $\mathrm{CH}_{4}$ & 49.74 & 28.11 & \\
$\mathrm{CO}_{2}$ & 50.26 & 49.86 & 19.88 \\
$\mathrm{~N}_{2}$ & & 22.03 & 80.12
\end{tabular}

\subsection{Experimental Apparatus}




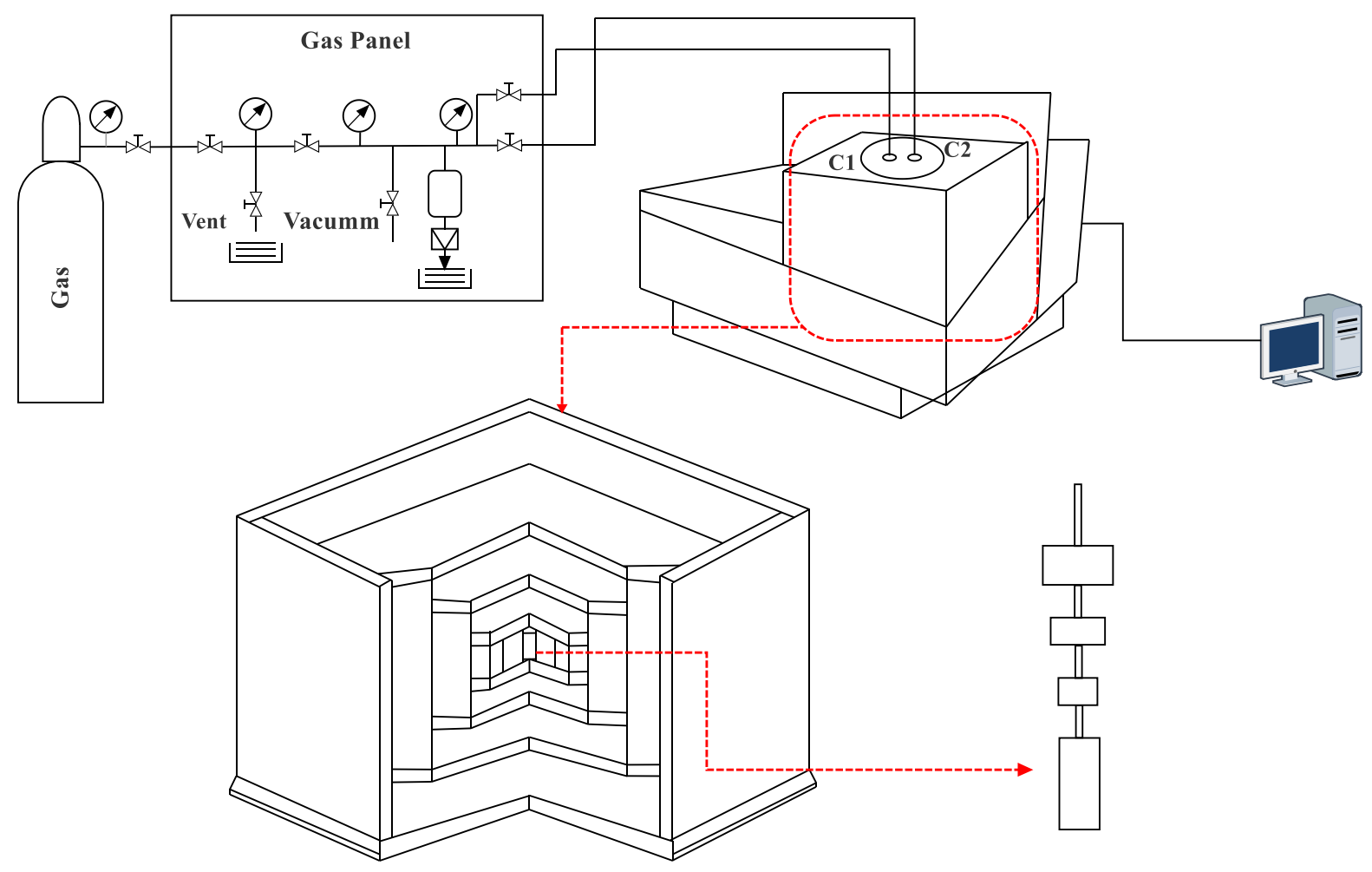

Figure 1. Schematic diagram of $\mu$-DSC apparatus: C1, reference cell; $\mathrm{C} 2$, sample cell.

A high pressure micro-differential scanning calorimeter (HP $\mu$-DSC VII Evo, Setaram Inc., France) was used to measure the dissociation temperature and enthalpies of gas hydrates. The $\mu$ DSC apparatus can be operated in pressure range of $0.1 \mathrm{MPa}$ to $40.0 \mathrm{MPa}$ and at temperatures from $228.15 \mathrm{~K}$ to $393.15 \mathrm{~K}$, it has a resolution of $0.02 \mu \mathrm{W}$. The schematic diagram of $\mu$-DSC apparatus is shown in Figure 1. The sample cell is made of Hastelloy C276 material to eliminate corrosion or contamination, with an internal diameter of $6.4 \mathrm{~mm}$ and a useful height equivalent to $19.5 \mathrm{~mm}$ for the sample. The sample cell is connected to the gas panel where the pressure can be preset to the desired value and measured using a pressure transducer with an accuracy of $\pm 0.25 \%$ (range: 0 to 20.0 MPa). Both the reference cell and sample cell are completely surrounded by a calorimetric furnace that can be heated or cooled from 0.001 to $1.2 \mathrm{~K} \cdot \mathrm{min}^{-1}$ using Peltier cooling/heating. The $\mu$ DSC setup was calibrated before performing experiments, and its accuracy can be checked against 
reference standard of the calibration substances, i.e, water, naphthalene and $n$-decane. Table 2 shows the comparison between the NIST data and the results of temperature and enthalpy calibration values, the maximum deviation in the transition temperature and the latent heat from the NIST data was $0.18 \mathrm{~K}$ and $0.15 \mathrm{~J} \cdot \mathrm{g}^{-1}$, respectively.

Table 2 The temperature and enthalpy calibration of $\mu$-DSC apparatus.

\begin{tabular}{ccccc}
\hline Material & $\begin{array}{c}\text { NIST } \\
\text { transition } \\
\text { temperature } \\
(\mathrm{K})\end{array}$ & $\begin{array}{c}\text { NIST } \\
\text { enthalphy } \\
\left(\mathrm{J} \cdot \mathrm{g}^{-1}\right)\end{array}$ & $\begin{array}{c}\text { DSC } \\
\text { transition } \\
\text { temperature } \\
(\mathrm{K})\end{array}$ & $\begin{array}{c}\text { DSC } \\
\text { enthalphy } \\
\left(\mathrm{J} \cdot \mathrm{g}^{-1}\right)\end{array}$ \\
\hline Water & 273.15 & 333.33 & 273.15 & 333.31 \\
Naphthalene & 353.38 & 147.6 & 353.41 & 147.45 \\
N-Decane & 244.15 & & 244.33 & \\
\hline
\end{tabular}

*NIST stands for National Institute of Standards and Technology.

\subsection{Experimental Procedures}

In the $\mu$-DSC experiment, hydrate nucleation and growth in static system of pure water is restricted due to mass transfer limitations and requires a high sub-cooling degree, which would lead to ice formation. In order to reduce the mass transfer resistance and achieve a high conversion of water to hydrate, the pure water was injected into three capillary tubes $(2.3 \mathrm{~mm}$ diameter and $0.8 \mathrm{~cm}$ length) with a micro-syringe. These tubes loaded water were then placed inside the sample cell, while the reference cell was empty for the heat flow measurements. Then, the $\mu$-DSC cells and all tubes were flushed with the test gas at least three times to remove any residual air. After that, methane was injected in the sample and reference cell through the gas panel until the desired experimental pressure was reached and temperature program was started. The experiments were performed under a constant temperature ramping program as shown in Figure 2, that is, the temperature decreased from $293.15 \mathrm{~K}$ to $243.15 \mathrm{~K}$ at the rate of $0.5 \mathrm{~K} \cdot \mathrm{min}^{-1}$, after keeping constant for a certain time at $243.15 \mathrm{~K}$, it increased from $243.15 \mathrm{~K}$ to $293.15 \mathrm{~K}$ at the rate of $0.25 \mathrm{~K} \cdot \mathrm{min}^{-1}$. A 
typical thermogram of $\mathrm{CH}_{4}$ hydrate during an experiment is shown in Figure 3. The hydrate or ice formation is identified by the exothermic peaks during the cooling cycle of a ramping experiment. More than one exothermic peak was observed due to hydrate or ice formation in the three capillaries, since the test capillary tubes are separated, a nucleation in one of the tubes will not affect the remaining. Subsequently during heating, two endothermic peaks are observed, the first one at 273.15 $\mathrm{K}$ indicates ice melting and the second at $286.15 \mathrm{~K}$ represents hydrate dissociation. The amount of heat required to dissociate the hydrate sample can be calculated by integrating the endothermic peak area. In the investigation of $\mathrm{CH}_{4}-\mathrm{CO}_{2} /\left(\mathrm{CO}_{2}+\mathrm{N}_{2}\right)$ swapping experiment, $\mathrm{CH}_{4}$ hydrate sample preparation procedure and temperature decreasing process is the same as above, after that the experimental temperature increased to a specified value which keep the hydrate and ice in the sample cannot melt and dissociate (at $263.15 \mathrm{~K}$ in this study), then the outlet valve was opened and free $\mathrm{CH}_{4}$ gas was released until the pressure reached the equilibrium pressure of $\mathrm{CH}_{4}$ hydrate at the experimental temperature $(1.844 \mathrm{MPa}$ at $263.15 \mathrm{~K})$. Subsequently the $\mathrm{CO}_{2}$ or $\left(\mathrm{CO}_{2}+\mathrm{N}_{2}\right)$ was injected into the reactor continually, the free gaseous $\mathrm{CH}_{4}$ in the tubes and cells was therefore brought out by $\mathrm{CO}_{2}$ or $\left(\mathrm{CO}_{2}+\mathrm{N}_{2}\right)$, it should be noted that the pressure in the reactor was maintained at the equilibrium pressure of methane hydrate to make sure that methane hydrate did not dissociate during the sweep process. When the composition of $\mathrm{CH}_{4}$ in the reactor was lower than $2 \%$, the outlet valve was closed and $\mathrm{CO}_{2}$ or $\left(\mathrm{CO}_{2}+\mathrm{N}_{2}\right)$ gas mixture was injected into the cells until the pressure attained a predefined value which is lower than the $\mathrm{CO}_{2}$ or $\left(\mathrm{CO}_{2}+\mathrm{N}_{2}\right)$ liquefaction pressures at experimental temperature. Thereafter, the swapping process was assumed to have started. Keeping the experimental temperature constant for a long time (at least $24 \mathrm{~h}$ ) to make sure the swapping reaction proceed completely, increasing the temperature to $293.15 \mathrm{~K}$ at the rate of $0.25 \mathrm{~K} \cdot \mathrm{min}^{-1}$ to investigate the dissociation behavior of mixed hydrates after swapping. 


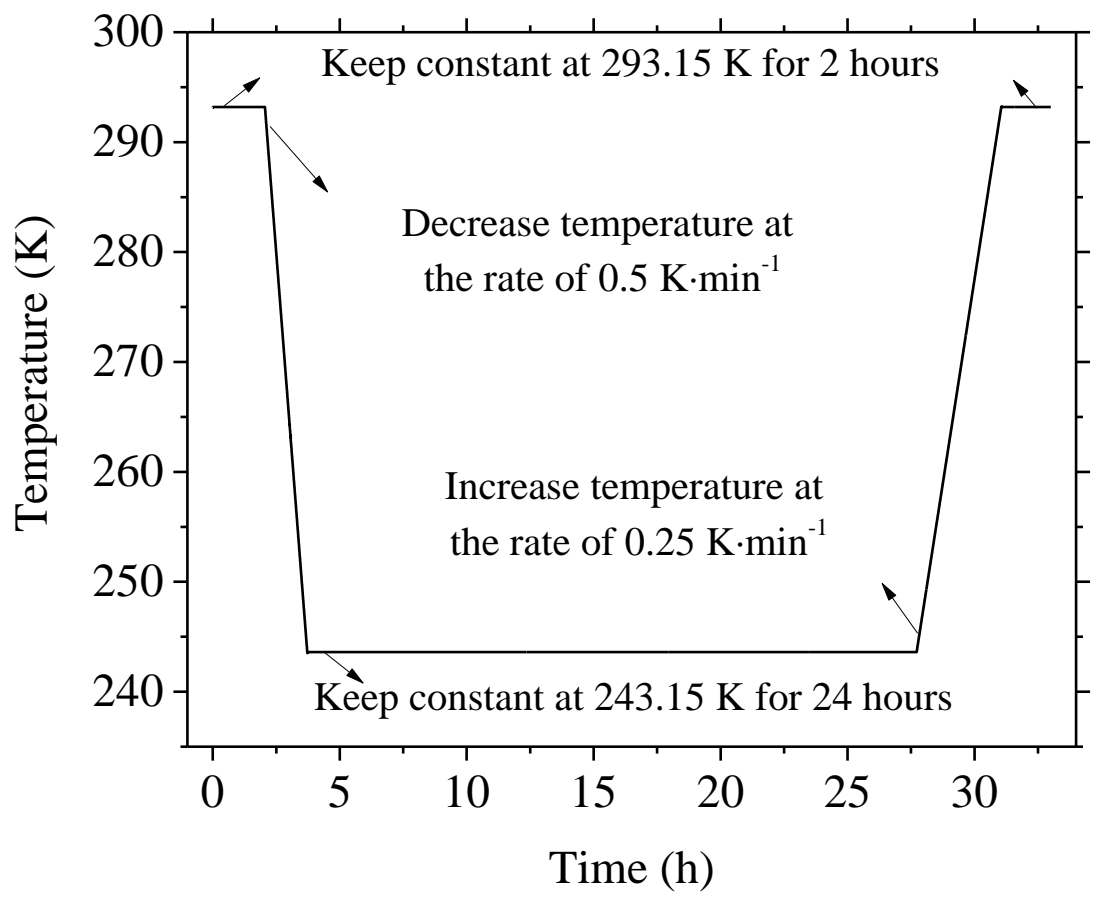

Figure 2. Changes of temperature during the whole cooling-heating cycles.

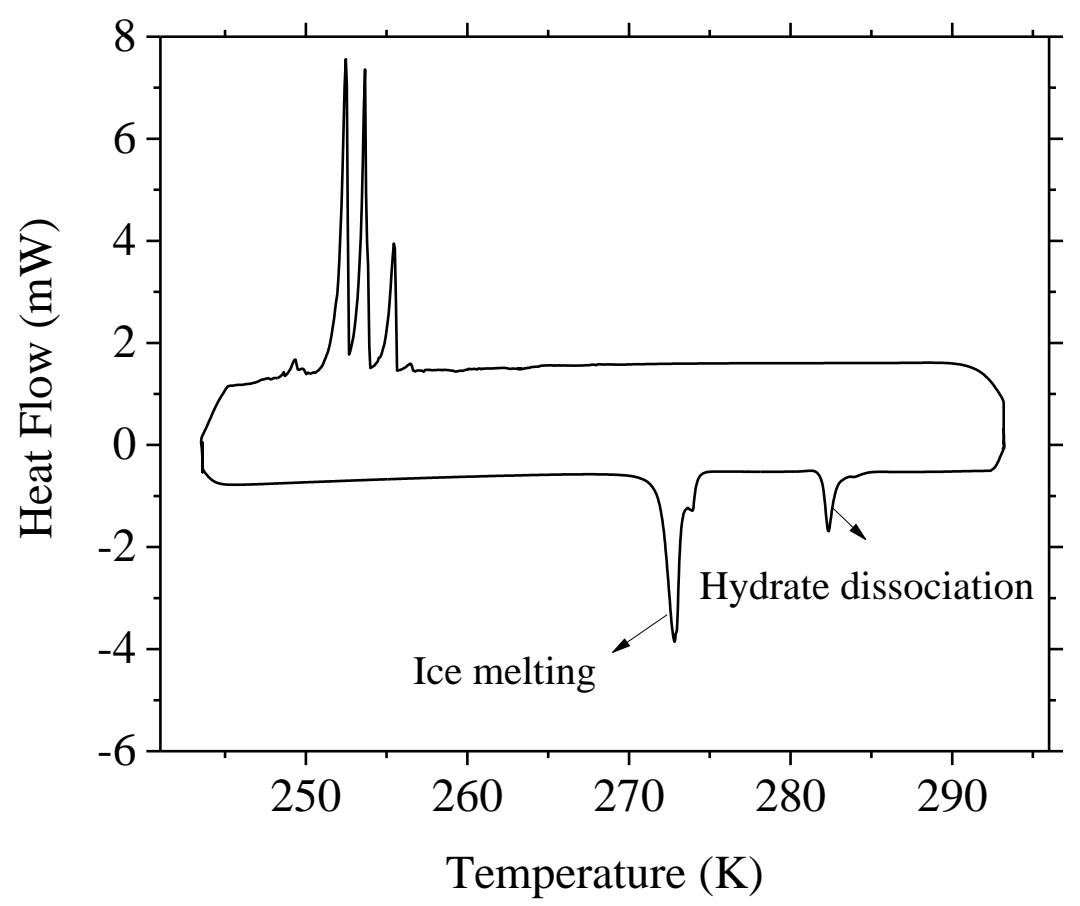

Figure 3. Changes of heat flow during the whole cooling-heating cycles. 


\subsection{Data processing}

In this work, we used two methods to calculate the dissociation enthalpies of hydrates, the first is integrating the endothermic peak area through $\mu$-DSC measurement results, and the second is calculating them by Clapeyron equation. The following two equations represent the dissociation reaction of hydrates to gas and water or ice, respectively:

$$
\begin{aligned}
& \mathrm{M} \cdot n \mathrm{H}_{2} \mathrm{O}(\mathrm{s}) \rightarrow \mathrm{M}(\mathrm{g})+n \mathrm{H}_{2} \mathrm{O}(\mathrm{l}) \\
& \mathrm{M} \cdot n \mathrm{H}_{2} \mathrm{O}(\mathrm{s}) \rightarrow \mathrm{M}(\mathrm{g})+n \mathrm{H}_{2} \mathrm{O}(\mathrm{s})
\end{aligned}
$$

Where $\mathrm{M}$ is a hydrate forming gas (or hydrate-forming gas mixture), $n$ is the hydration number. The difference in enthalpy between the two reactions is equal to the fusion enthalpy of ice, hence, we mainly focus on the dissociation enthalpy based on the reaction of hydrates to gas and liquid water in this work. The most sensitive parameter in calculating the enthalpy of hydrate dissociation is the mass of reaction water associated with the hydrate and the mass of free water or ice in the sample. The accurate amount of free water, $m_{\mathrm{i}}$, can be calculated and confirmed from the endothermic peak area of ice melting using an ice melting enthalpy of $333.33 \mathrm{~J} \cdot \mathrm{g}^{-1}$ :

$$
m_{\mathrm{i}}=\frac{Q_{\mathrm{i}}}{333.33}
$$

Where $Q_{\mathrm{i}}$ is the amount of heat which ice melting released, and it can be calculated by integrating the endothermic peak area of ice melting. Then the enthalpy of hydrate dissociation per mole of producing gas, $\Delta H_{d}$, can be calculated by:

$$
\Delta H_{d}=\frac{Q_{\mathrm{h}}}{m_{\mathrm{t}}-m_{\mathrm{i}}} \times M_{\mathrm{W}} \times n
$$

Where $Q_{\mathrm{h}}$ is the amount of heat absorbed in hydrate dissociation process, and also it can be calculated by integrating the endothermic peak area of hydrate dissociation correspondingly, $m_{\mathrm{t}}$ is 
the total mass of water in the sample cell, $M_{\mathrm{W}}$ is the molar mass of water. Circone et al. [2] showed that the hydration number for methane hydrate does not change within the pressure and temperature conditions ranged from 1.9 to $9.7 \mathrm{MPa}$ and 263 to $285 \mathrm{~K}$, the average hydrate composition is found to be $\mathrm{CH}_{4} \cdot 5.99( \pm 0.07) \mathrm{H}_{2} \mathrm{O}$, therefore, a hydration number of 6.0 is used here. As for the hydration number of the $\mathrm{CO}_{2}$ hydrate and other mixed hydrates, it takes 6.0 in this work according to some researchers' reports [32-34].

Clapeyron equation is widely used to obtain enthalpy changes involved in the pure component phase transition process. It was suggested by van der Waals and Platteeuw [35] that Clapeyron equation could be applied to calculate the dissociation enthalpy of the clathrate hydrate along the three phase equilibrium line. The dissociation enthalpy can be calculated from the slope of the three phase line and the change in molar volume using the Clapeyron equation for hydrate to water and gas reaction by:

$$
\frac{d P}{d T}=\frac{\Delta H_{d}}{T \Delta V}
$$

Where, $P$ and $T$ are the absolute pressure and temperature, $\Delta V$ is the molar volume change due to the phase transition from hydrate to water and gas, can be calculated by:

$$
\Delta V=V_{\mathrm{G}}+n V_{\mathrm{W}}-V_{\mathrm{H}}
$$

Where, $V_{\mathrm{G}}, V_{\mathrm{W}}, V_{\mathrm{H}}$ are the molar volume of gas, water and hydrate, respectively. The water and gas molar volume can be obtained using national institute of standard and technology (NIST) program,

and $V_{\mathrm{H}}, \frac{d P}{d T}$ can be calculated with Anderson's method [36,37]. Substituting Equation (6) into the Clapeyron equation, the expression for hydrate dissociation enthalpy is obtained,

$$
\Delta H_{d}=T \times\left(V_{\mathrm{G}}+n V_{\mathrm{W}}-V_{\mathrm{H}}\right) \times \frac{d P}{d T}
$$

\section{Results and disscusion}

\subsection{Onset temperature and enthalpies of hydrate dissociation by $\mu$-DSC measurements}


A series of $\mu$-DSC measurements were conducted to investigate the dissociation behavior of various hydrates. Figure 4, 5, 6 and 7 showed the dissociation thermograms of $\mathrm{CH}_{4}$ hydrate, $\mathrm{CO}_{2}$ hydrate, $\mathrm{M}_{1}$ binary hydrates and $\mathrm{M}_{2}$ ternary hydrates at different experimental conditions. Since the endothermic peak from ice melting is detected at $273.15 \mathrm{~K}$ in each experimental run, it hasn't been present in these figures to make sure the peak caused by hydrate dissociation is more clearly. At a certain pressure condition, the onset temperature of endothermic peak which is marked in each dissociation thermogram, is taken as the hydrate initial dissociation temperature in three phase transition process. The heat flow decreases remarkably from the onset temperature point, and it consists of water-hydrate-gas three phase until the offset temperature point at which the heat flow return its baseline. As we can see from the figures, most dissociation thermograms of pure $\mathrm{CH}_{4}$ or $\mathrm{CO}_{2}$ hydrate are smooth and have a single peak detected in each experimental run, however, some of the dissociation thermograms of binary or ternary hydrates present a small peak which followed close behind the main peak, especially in ternary hydrates system at the higher pressure conditions. The reason might be there are more than one guest molecule in binary or ternary hydrates structure and the dissociation conditions of hydrate formed by each guest molecule are different, a kind of guest molecule escape from the hydrate clathrate would lead to the cage become unstable or destroyed and release the other guest molecules.

In Figure 8, the hydrate dissociation equilibrium data obtained from the $\mu$-DSC measurements are compared with the calculated values by CSMGem model [1]. The CSMGem model results are actually the H-L-V three phase equilibrium boundaries in hydrate formation process, and they are basically the same as that of the dissociation process [38]. In this study, the CSMGem model results are used for dissociation equilibrium boundaries, since we can calculate the hydrate composition for binary and ternary hydrates with it. As we can see from Figure 8 , the $\mu$-DSC measurements have a good agreement with CSMGem model calculations. In addition, it also demonstrated and confirmed 
that the $\mu$-DSC can provide accurate H-L-V equilibrium data for the single or multi guest molecules hydrates system. By integrating the endothermic peaks and calculating according to equation (4), the dissociation enthalpies of hydrates are obtained and list in Table 3 and 4. The average dissociation enthalpy of $\mathrm{CH}_{4}$ hydrate is $55.04 \mathrm{~kJ} \cdot \mathrm{mol}^{-1}$ in the range of temperature $275.54-286.35 \mathrm{~K}$ and pressure $3.163-10.143 \mathrm{MPa}$, while that of $\mathrm{CO}_{2}$ hydrate is $58.95 \mathrm{~kJ} \cdot \mathrm{mol}^{-1}$ in the range of temperature $273.54-277.57 \mathrm{~K}$ and pressure $1.290-2.114 \mathrm{MPa}$, which is a litter higher than that of $\mathrm{CH}_{4}$ hydrate. As we can see from the results, the dissociation enthalpies of hydrates did not show any temperature and pressure dependence in experimental condition. The dissociation enthalpies of $\mathrm{M}_{1}$ binary and $\mathrm{M}_{2}$ ternary hydrates are between that of the pure $\mathrm{CH}_{4}$ hydrate and that of the pure $\mathrm{CO}_{2}$ hydrate. In addition, it was observed that the dissociation enthalpy of $\mathrm{M}_{1}$ binary hydrates increased with the mole fraction of $\mathrm{CO}_{2}$ in hydrate phase, as shown in Figure 9, and this result is consistent with Kwon's [21] investigation and Lee's [29] study. It has the similar tendency as well in the $\mathrm{M}_{2}$ ternary hydrates system, since the mole fraction of $\mathrm{N}_{2}$ in hydrate phase is much lower and the dissociation enthalpy is mainly depending on the concentration of $\mathrm{CO}_{2}$ and $\mathrm{CH}_{4}$ in hydrate phase. 


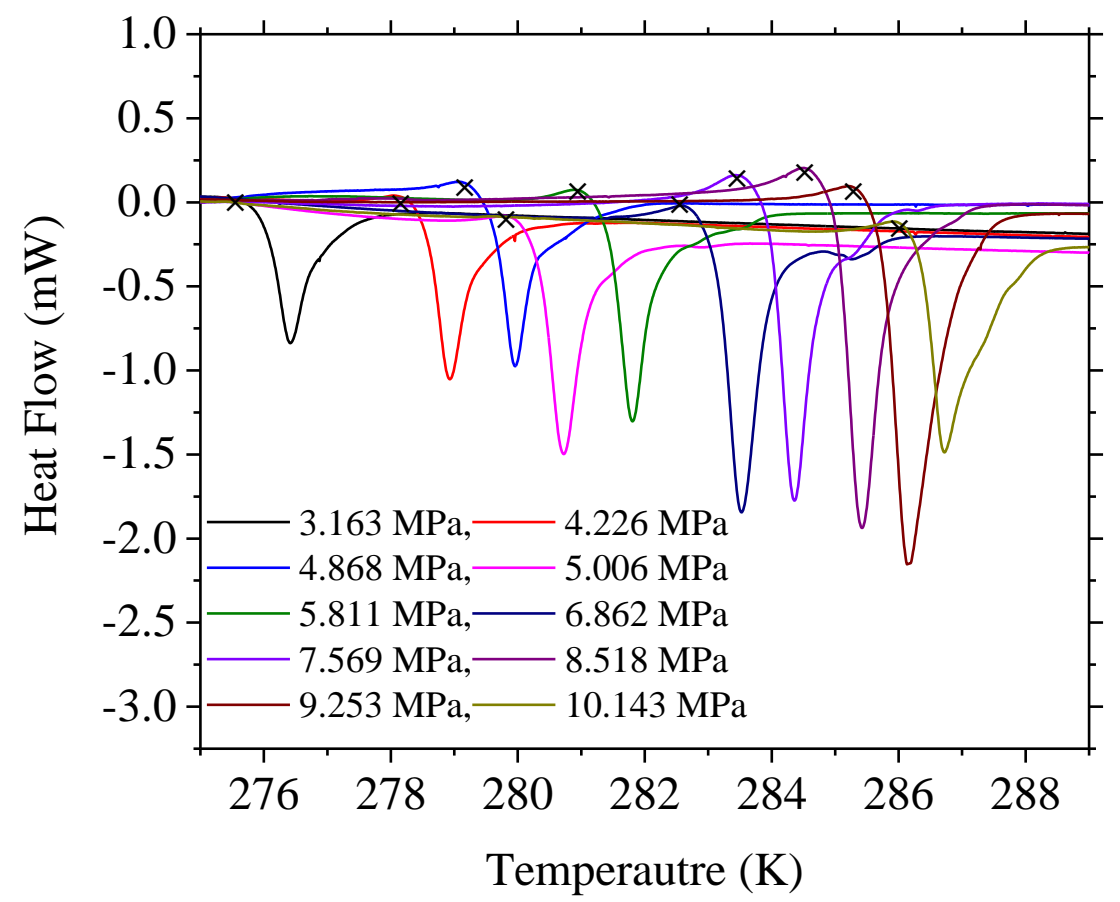

Figure 4. The dissociation thermograms of $\mathrm{CH}_{4}$ hydrate at different pressure conditions.

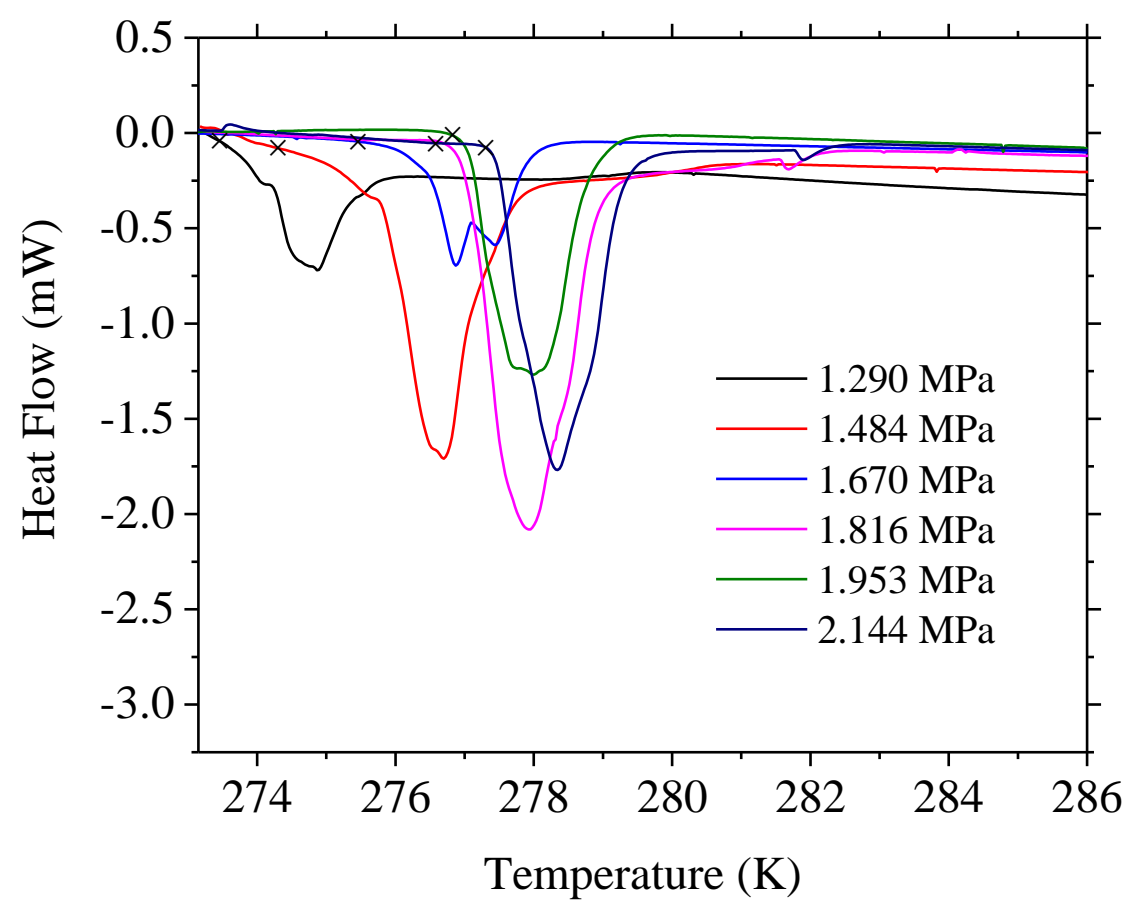

Figure 5. The dissociation thermograms of $\mathrm{CO}_{2}$ hydrate at different pressures. 


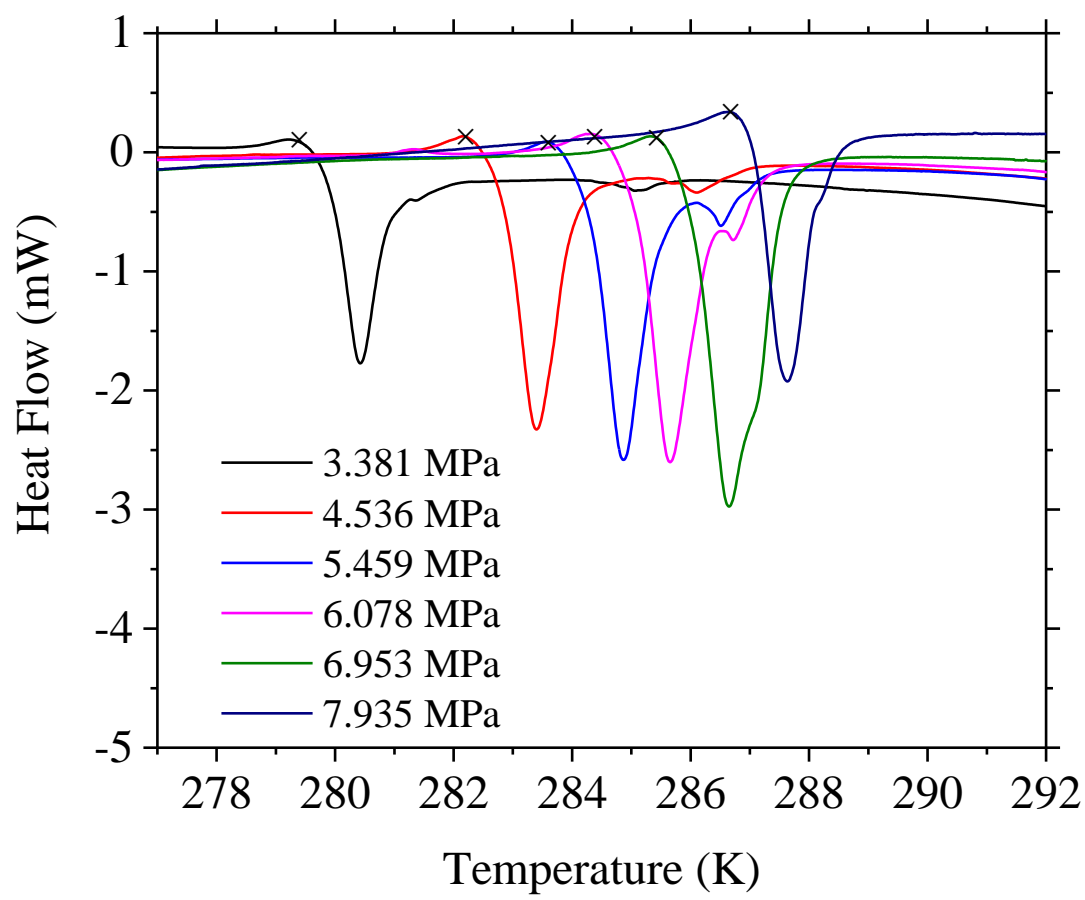

Figure 6. The dissociation thermograms of $\mathrm{M}_{1}$ binary hydrate at different pressures.

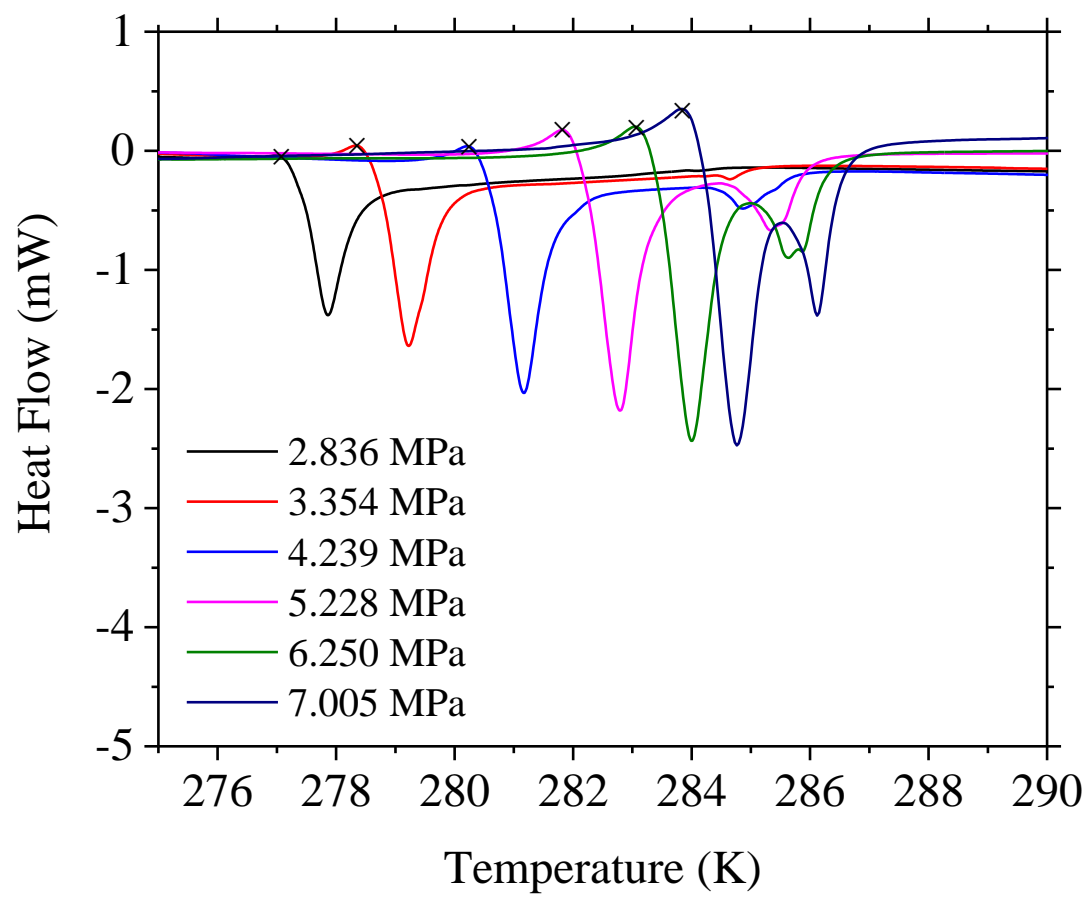


Figure 7. The dissociation thermograms of $\mathrm{M}_{2}$ ternary hydrate at different pressures.

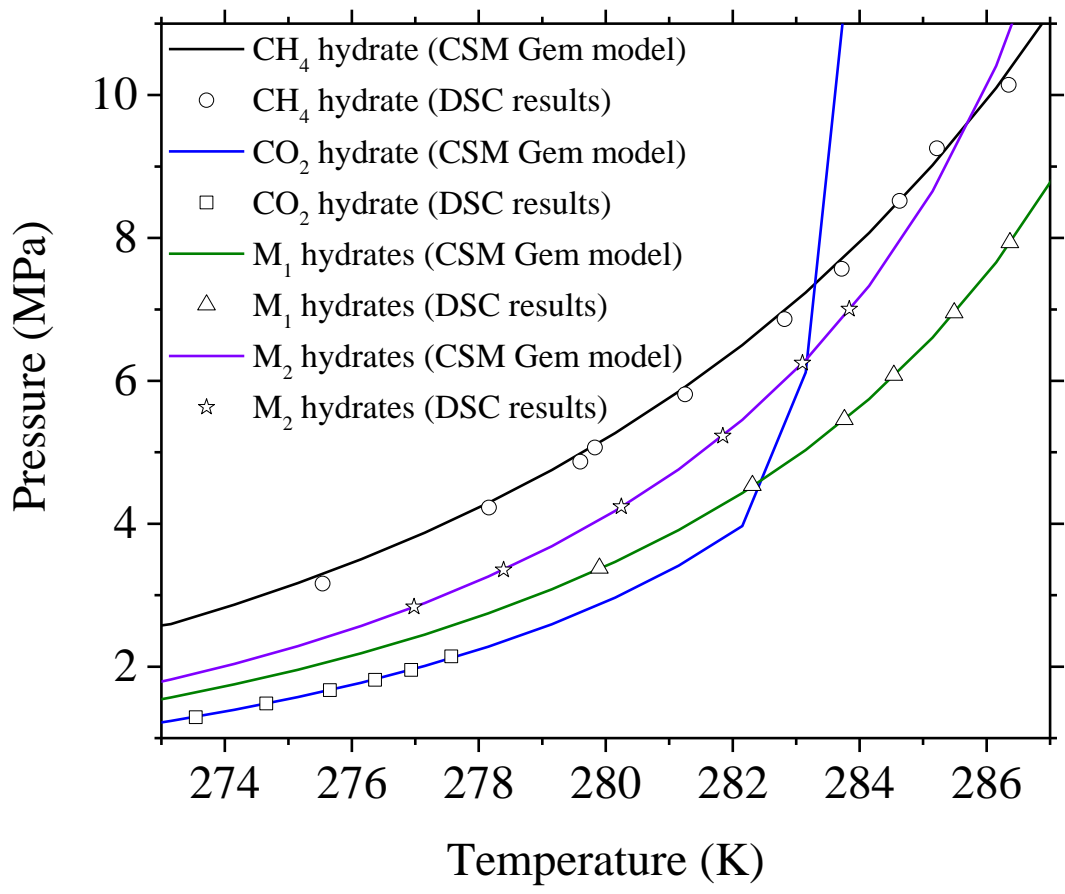

Figure 8. Comparison of hydrate dissociation equilibrium data from the $\mu$-DSC measurements and CSMGem model calculation.

Table 3 The $\mu$-DSC measurement results and dissociation enthalpies of pure $\mathrm{CH}_{4}$ and $\mathrm{CO}_{2}$ hydrate.

\begin{tabular}{ccccccc}
\hline Run & $T_{\text {onset }}(\mathrm{K})$ & $P(\mathrm{MPa})$ & $m_{\mathrm{W}}(\mathrm{mg})$ & $\begin{array}{c}x_{\mathrm{I}} \\
(\mathrm{wt} \%)\end{array}$ & $\begin{array}{c}x_{\mathrm{H}} \\
(\mathrm{wt} \%)\end{array}$ & $\begin{array}{c}\Delta H_{d} \\
\left(\mathrm{~kJ} \cdot \mathrm{mol}^{-1}\right)\end{array}$ \\
\hline 1 & 275.54 & 3.163 & $\frac{\mathrm{CH}_{4} \text { hydrate }}{2.8}$ & 89.36 & 10.64 & 55.09 \\
2 & 278.16 & 4.226 & 2.1 & 82.60 & 17.40 & 54.98 \\
3 & 279.60 & 4.868 & 2.8 & 85.93 & 14.07 & 55.10 \\
4 & 279.83 & 5.066 & 2.0 & 74.76 & 25.24 & 54.99 \\
5 & 281.25 & 5.811 & 2.7 & 81.61 & 18.39 & 55.02 \\
6 & 282.82 & 6.862 & 3.7 & 77.88 & 22.12 & 55.02 \\
7 & 283.72 & 7.569 & 3.0 & 72.70 & 27.30 & 54.99 \\
8 & 284.63 & 8.518 & 2.9 & 75.39 & 24.61 & 54.92 \\
9 & 285.22 & 9.253 & 2.9 & 61.66 & 38.34 & 54.97 \\
10 & 286.35 & 10.143 & 2.7 & 77.97 & 22.03 & 55.01 \\
& & & $\mathrm{CO}_{2}$ hydrate & & & \\
11 & 273.54 & 1.290 & 2.1 & 60.57 & 39.43 & 58.96 \\
12 & 274.65 & 1.484 & 2.7 & 77.22 & 22.78 & 59.01 \\
\hline
\end{tabular}




\begin{tabular}{lllllll}
\hline 13 & 275.66 & 1.670 & 2.3 & 87.57 & 12.43 & 58.76 \\
14 & 276.37 & 1.816 & 3.4 & 59.12 & 40.88 & 58.97 \\
15 & 276.94 & 1.953 & 2.0 & 34.50 & 65.50 & 58.95 \\
16 & 277.57 & 2.144 & 2.1 & 66.57 & 33.43 & 59.08 \\
\hline
\end{tabular}

$* x_{\mathrm{I}}, x_{\mathrm{H}}$ are the mass fraction of ice and hydrate phase, respectively, similarly hereinafter.

Table 4 The $\mu$-DSC measurement results and dissociation enthalpies of binary and ternary hydrates.

\begin{tabular}{|c|c|c|c|c|c|c|c|c|c|}
\hline Run & $T_{\text {onset }}(\mathrm{K})$ & $P(\mathrm{MPa})$ & $m_{\mathrm{W}}(\mathrm{mg})$ & $\begin{array}{c}x_{\mathrm{I}} \\
(\mathrm{wt} \%)\end{array}$ & $\begin{array}{c}x_{\mathrm{H}} \\
(\mathrm{wt} \%)\end{array}$ & $\begin{array}{c}C_{\mathrm{CH}_{4}}^{\mathrm{H}} \\
(\mathrm{mol} \%)\end{array}$ & $\begin{array}{c}C_{\mathrm{CO}_{2}}^{\mathrm{H}} \\
(\mathrm{mol} \%)\end{array}$ & $\begin{array}{c}C_{\mathrm{N}_{2}}^{\mathrm{H}} \\
(\mathrm{mol} \%)\end{array}$ & $\begin{array}{c}\Delta H_{d} \\
\left(\mathrm{~kJ} \cdot \mathrm{mol}^{-1}\right)\end{array}$ \\
\hline \multicolumn{10}{|c|}{$\mathrm{M}_{1}$ binary hydrates } \\
\hline 17 & 279.90 & 3.381 & 2.5 & 68.28 & 31.72 & 35.71 & 64.29 & - & 57.47 \\
\hline 18 & 282.31 & 4.536 & 3.0 & 59.60 & 40.40 & 37.22 & 62.78 & - & 57.30 \\
\hline 19 & 283.76 & 5.459 & 2.4 & 46.63 & 53.37 & 38.41 & 61.59 & - & 57.25 \\
\hline 20 & 284.54 & 6.078 & 2.4 & 45.00 & 55.00 & 39.21 & 60.79 & - & 57.19 \\
\hline 21 & 285.49 & 6.953 & 2.3 & 35.74 & 64.26 & 40.38 & 59.62 & - & 57.14 \\
\hline 22 & 286.37 & 7.935 & 2.4 & 42.50 & 57.50 & 41.75 & 58.25 & - & 57.05 \\
\hline \multicolumn{10}{|c|}{$\mathrm{M}_{2}$ ternary hydrates } \\
\hline 23 & 276.98 & 2.836 & 3.7 & 76.95 & 23.05 & 22.69 & 73.59 & 3.72 & 57.61 \\
\hline 24 & 278.39 & 3.354 & 3.8 & 72.62 & 27.38 & 23.20 & 72.91 & 3.89 & 57.50 \\
\hline 25 & 280.25 & 4.239 & 4.0 & 68.70 & 31.30 & 24.01 & 71.83 & 4.16 & 57.38 \\
\hline 26 & 281.84 & 5.228 & 4.1 & 66.15 & 33.85 & 24.88 & 70.66 & 4.47 & 57.35 \\
\hline 27 & 283.10 & 6.250 & 4.1 & 64.03 & 35.97 & 25.77 & 69.44 & 4.79 & 57.26 \\
\hline 28 & 283.84 & 7.005 & 4.4 & 63.61 & 36.39 & 26.43 & 68.54 & 5.03 & 57.14 \\
\hline
\end{tabular}

$* C_{\mathrm{CH}_{4}}^{\mathrm{H}}, C_{\mathrm{CO}_{2}}^{\mathrm{H}}, C_{\mathrm{N}_{2}}^{\mathrm{H}}$ are the mole fraction of $\mathrm{CH}_{4}, \mathrm{CO}_{2}, \mathrm{~N}_{2}$ in hydrate phase, respectively, which were calculated with CSMGem model, similarly hereinafter. 


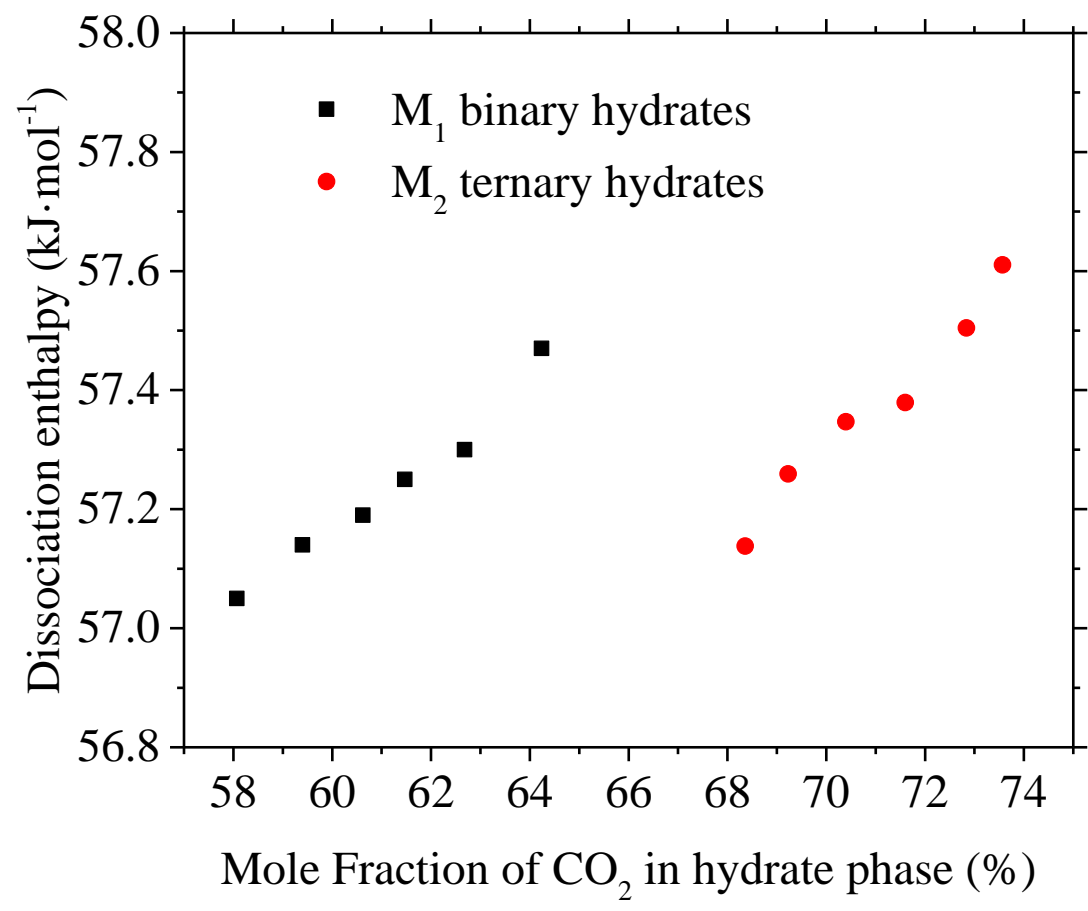

Figure 9. Dissociation enthalpies of the $\mathrm{M}_{2}$ binary and $\mathrm{M}_{3}$ ternary hydrates with respect to the $\mathrm{CO}_{2}$ composition in hydrate phase.

\subsection{Dissociation enthalpies of various hydrates calculated with Clapeyron equation.}

Clapeyron equation relates the enthalpy change of a phase equilibrium reaction to the volumetric properties of the reactants and products along the phase boundary, van der Waals [39] pointed out that the validity of Clapeyron equation depends on the fact that the reaction in either of Equation (1) or (2) is univariant. According to Gibbs phase rule, the number of components and phases in the single guest molecule hydrate system are 2 and 3, it is univariant at the three-phase equilibrium conditions. Strictly speaking, it is not univariant for the dissociation process of the $\left(\mathrm{CH}_{4}+\mathrm{CO}_{2}\right)$ binary and $\left(\mathrm{CH}_{4}+\mathrm{CO}_{2}+\mathrm{N}_{2}\right)$ ternary hydrates. However, many researchers calculated the dissociation enthalpies of some binary and ternary hydrates using Clausius-Clapeyron equation [40-43], which is derived from Clapeyron equation, by treating the multicomponent guest molecules as a single. Besides, in their study, they simply assumed that the volume change in hydrate dissociation phase 
transition process is equal to the gas volume, and supposed that the slope of the three-phase equilibrium curve is not changing with pressure and temperature. These assumptions lead to a large relative error in the predictions even for univariant system, and Gupta et al. [28] has investigated and validated it in their research. Hence, here we present the calculation of dissociation enthalpy for the single guest hydrate using Clapeyron equations, and tried to estimate the dissociation enthalpy of binary and ternary hydrates, they are list in Table 5 and 6 , respectively. Table 5 showed the predictions of dissociation enthalpy depending on the phase equilibrium data obtained from $\mu$-DSC measurements. In this study, the dissociation enthalpy was calculated according to Anderson's method [36,37]. The slope of the three-phase equilibrium curve at any temperature, $\frac{d P}{d T}$, was determined by first developing a polynomial equation, and then differentiating with temperature. The volume change from hydrate to gas and water, $\Delta V$, was calculated using $\Delta V=V_{\mathrm{G}}+n V_{\mathrm{W}}-V_{\mathrm{H}}$ instead of assuming $\Delta V=V_{\mathrm{G}}$. This method takes into account the finite volumes of the condensed phases, the non-ideality of the vapor phase, and the solubility of carbon dioxide and methane in water. As shown in Table 5, the dissociation enthalpies of $\mathrm{CH}_{4}$ hydrate and $\mathrm{CO}_{2}$ hydrate at different temperature are very close to $\mu$-DSC measurement results. It also demonstrated that the dissociation enthalpies calculation in $\mu$-DSC measurements was accurate. As far as the dissociation enthalpies of binary or ternary hydrates system, we calculated them using Clapeyron equation and list in Table 6, most of the calculation results are close to $\mu$-DSC measurements with some exceptions, for example, the endpoint data have a relative error might because of differentiating in the calculation process, we believe the most accurate way is to measure it calorimetrically.

Table 5 The dissociation enthalpy calculation of $\mathrm{CH}_{4}$ and $\mathrm{CO}_{2}$ hydrate with Clapeyron equation.

\begin{tabular}{ccccccccc}
\hline Run & $\begin{array}{c}T_{\text {onset }} \\
(\mathrm{K})\end{array}$ & $\begin{array}{c}P \\
(\mathrm{MPa})\end{array}$ & $\begin{array}{c}d P / d T \\
\left(\mathrm{MPa} \cdot \mathrm{K}^{-1}\right)\end{array}$ & $\begin{array}{c}V_{\mathrm{G}} \\
\left(\mathrm{m}^{3} \cdot \mathrm{mol}^{-1}\right)\end{array}$ & $\begin{array}{c}V_{\mathrm{w}} \\
\left(\mathrm{m}^{3} \cdot \mathrm{mol}^{-1}\right)\end{array}$ & $\begin{array}{c}V_{\mathrm{H}} \\
\left(\mathrm{m}^{3} \cdot \mathrm{mol}^{-1}\right)\end{array}$ & $\begin{array}{c}\Delta V \\
\left(\mathrm{~m}^{3} \cdot \mathrm{mol}^{-1}\right)\end{array}$ & $\begin{array}{c}\Delta H_{d} \\
\left(\mathrm{~kJ} \cdot \mathrm{mol}^{-1}\right)\end{array}$ \\
\hline \multicolumn{10}{c}{$\mathrm{CH}_{4}$ hydrate } \\
\hline
\end{tabular}




\begin{tabular}{ccccccccc}
\hline 1 & 275.54 & 3.163 & 0.316 & $6.704 \mathrm{E}-04$ & $1.797 \mathrm{E}-05$ & $1.343 \mathrm{E}-04$ & $6.393 \mathrm{E}-04$ & 55.64 \\
2 & 278.16 & 4.226 & 0.419 & $4.954 \mathrm{E}-04$ & $1.796 \mathrm{E}-05$ & $1.343 \mathrm{E}-04$ & $4.646 \mathrm{E}-04$ & 55.42 \\
3 & 279.60 & 4.868 & 0.480 & $4.269 \mathrm{E}-04$ & $1.796 \mathrm{E}-05$ & $1.343 \mathrm{E}-04$ & $3.966 \mathrm{E}-04$ & 55.48 \\
4 & 279.83 & 5.066 & 0.522 & $4.088 \mathrm{E}-04$ & $1.796 \mathrm{E}-05$ & $1.343 \mathrm{E}-04$ & $3.787 \mathrm{E}-04$ & 55.31 \\
5 & 281.25 & 5.811 & 0.598 & $3.532 \mathrm{E}-04$ & $1.795 \mathrm{E}-05$ & $1.344 \mathrm{E}-04$ & $3.235 \mathrm{E}-04$ & 55.39 \\
6 & 282.82 & 6.862 & 0.735 & $2.951 \mathrm{E}-04$ & $1.795 \mathrm{E}-05$ & $1.344 \mathrm{E}-04$ & $2.652 \mathrm{E}-04$ & 55.16 \\
7 & 283.72 & 7.569 & 0.823 & $2.652 \mathrm{E}-04$ & $1.794 \mathrm{E}-05$ & $1.344 \mathrm{E}-04$ & $2.356 \mathrm{E}-04$ & 55.03 \\
8 & 284.63 & 8.518 & 0.942 & $2.328 \mathrm{E}-04$ & $1.794 \mathrm{E}-05$ & $1.344 \mathrm{E}-04$ & $2.034 \mathrm{E}-04$ & 54.56 \\
9 & 285.22 & 9.253 & 1.047 & $2.123 \mathrm{E}-04$ & $1.793 \mathrm{E}-05$ & $1.344 \mathrm{E}-04$ & $1.832 \mathrm{E}-04$ & 54.11 \\
10 & 286.35 & 10.143 & 1.152 & $1.924 \mathrm{E}-04$ & $1.793 \mathrm{E}-05$ & $1.344 \mathrm{E}-04$ & $1.629 \mathrm{E}-04$ & 54.25 \\
& & & & & & & \\
11 & 273.54 & 1.290 & 0.153 & $1.601 \mathrm{E}-03$ & $1.833 \mathrm{E}-05$ & $1.389 \mathrm{E}-04$ & $1.414 \mathrm{E}-03$ & 59.25 \\
12 & 274.65 & 1.484 & 0.177 & $1.377 \mathrm{E}-03$ & $1.833 \mathrm{E}-05$ & $1.389 \mathrm{E}-04$ & $1.212 \mathrm{E}-03$ & 59.04 \\
13 & 275.66 & 1.670 & 0.203 & $1.210 \mathrm{E}-03$ & $1.835 \mathrm{E}-05$ & $1.389 \mathrm{E}-04$ & $1.053 \mathrm{E}-03$ & 58.79 \\
14 & 276.37 & 1.816 & 0.223 & $1.103 \mathrm{E}-03$ & $1.838 \mathrm{E}-05$ & $1.389 \mathrm{E}-04$ & $9.478 \mathrm{E}-04$ & 58.51 \\
15 & 276.94 & 1.953 & 0.242 & $1.027 \mathrm{E}-03$ & $1.838 \mathrm{E}-05$ & $1.389 \mathrm{E}-04$ & $8.808 \mathrm{E}-04$ & 59.09 \\
16 & 277.57 & 2.144 & 0.266 & $9.118 \mathrm{E}-04$ & $1.838 \mathrm{E}-05$ & $1.389 \mathrm{E}-04$ & $7.862 \mathrm{E}-04$ & 57.50 \\
\hline
\end{tabular}

Table 6 The dissociation enthalpy calculation of binary and ternary hydrates with Clapeyron equation.

\begin{tabular}{|c|c|c|c|c|c|c|c|c|}
\hline Run & $\begin{array}{l}T_{\text {onset }} \\
(\mathrm{K})\end{array}$ & $\begin{array}{c}P \\
(\mathrm{MPa})\end{array}$ & $\begin{array}{c}d P / d T \\
\left(\mathrm{MPa} \cdot \mathrm{K}^{-1}\right)\end{array}$ & $\begin{array}{c}V_{\mathrm{G}} \\
\left(\mathrm{m}^{3} \cdot \mathrm{mol}^{-1}\right)\end{array}$ & $\begin{array}{c}V_{\mathrm{w}} \\
\left(\mathrm{m}^{3} \cdot \mathrm{mol}^{-1}\right)\end{array}$ & $\begin{array}{c}V_{\mathrm{H}} \\
\left(\mathrm{m}^{3} \cdot \mathrm{mol}^{-1}\right)\end{array}$ & $\begin{array}{c}\Delta V \\
\left(\mathrm{~m}^{3} \cdot \mathrm{mol}^{-1}\right)\end{array}$ & $\begin{array}{c}\Delta H_{d} \\
\left(\mathrm{~kJ} \cdot \mathrm{mol}^{-1}\right)\end{array}$ \\
\hline \multicolumn{9}{|c|}{$\mathrm{M}_{1}$ binary hydrates } \\
\hline 17 & 279.90 & 3.381 & 0.398 & $5.788 \mathrm{E}-04$ & $1.835 \mathrm{E}-05$ & 1.389E-04 & 4.885E-04 & 54.36 \\
\hline 18 & 282.31 & 4.536 & 0.570 & 4.090E-04 & $2.265 \mathrm{E}-05$ & $1.389 \mathrm{E}-04$ & $3.487 \mathrm{E}-04$ & 56.15 \\
\hline 19 & 283.76 & 5.459 & 0.727 & $3.231 \mathrm{E}-04$ & $2.265 \mathrm{E}-05$ & $1.389 \mathrm{E}-04$ & $2.749 \mathrm{E}-04$ & 56.68 \\
\hline 20 & 284.54 & 6.078 & 0.840 & $2.814 \mathrm{E}-04$ & $2.265 \mathrm{E}-05$ & $1.389 \mathrm{E}-04$ & $2.390 \mathrm{E}-04$ & 57.16 \\
\hline 21 & 285.49 & 6.953 & 1.016 & $2.344 \mathrm{E}-04$ & $2.265 \mathrm{E}-05$ & $1.389 \mathrm{E}-04$ & $1.986 \mathrm{E}-04$ & 57.60 \\
\hline 22 & 286.37 & 7.935 & 1.220 & $1.944 \mathrm{E}-04$ & $2.265 \mathrm{E}-05$ & $1.389 \mathrm{E}-04$ & $1.642 \mathrm{E}-04$ & 57.40 \\
\hline \multicolumn{9}{|c|}{$\mathrm{M}_{2}$ ternary hydrates } \\
\hline 23 & 276.98 & 2.836 & 0.343 & $6.892 \mathrm{E}-04$ & $1.820 \mathrm{E}-05$ & $1.389 \mathrm{E}-04$ & $6.178 \mathrm{E}-04$ & 58.68 \\
\hline 24 & 278.39 & 3.354 & 0.405 & $5.666 \mathrm{E}-04$ & $1.820 \mathrm{E}-05$ & $1.389 \mathrm{E}-04$ & $5.026 \mathrm{E}-04$ & 56.67 \\
\hline 25 & 280.25 & 4.239 & 0.533 & 4.278E-04 & $1.820 \mathrm{E}-05$ & $1.389 \mathrm{E}-04$ & $3.722 \mathrm{E}-04$ & 55.60 \\
\hline 26 & 281.84 & 5.228 & 0.718 & $3.253 \mathrm{E}-04$ & $1.820 \mathrm{E}-05$ & $1.389 \mathrm{E}-04$ & $2.759 \mathrm{E}-04$ & 55.84 \\
\hline 27 & 283.10 & 6.250 & 0.933 & $2.526 \mathrm{E}-04$ & $1.820 \mathrm{E}-05$ & $1.389 \mathrm{E}-04$ & $2.076 \mathrm{E}-04$ & 54.81 \\
\hline 28 & 283.84 & 7.005 & 1.094 & $2.131 \mathrm{E}-04$ & $1.861 \mathrm{E}-05$ & $1.389 \mathrm{E}-04$ & $1.730 \mathrm{E}-04$ & 53.71 \\
\hline
\end{tabular}

\subsection{Comparison with the dissociation enthalpies in literature.}


The dissociation enthalpies of various gas hydrates in literature are listed in Table 7 . The hydrate dissociation enthalpies reflect the magnitude of stabilization due to the interactions between guest and host molecules. The guest molecules prevent interaction between opposite water molecules and thereby keep the lattice from collapsing, the empty hydrate lattices are thermodynamically unstable. In this work, by using of $\mu$-DSC method and Clapeyron equation calculation, the average values of $\mathrm{CH}_{4}$ hydrate dissociation enthalpies in the range of temperature $275.54-286.35 \mathrm{~K}$ and pressure 3.163-10.173 MPa are 55.04 and $55.12 \mathrm{~kJ} \cdot \mathrm{mol}^{-1}$, respectively, they are very close to the previous research results. However, the average value of $\mathrm{CO}_{2}$ hydrate dissociation enthalpies in the range of temperature 273.54-277.57 $\mathrm{K}$ and pressure 1.290-2.144 $\mathrm{MPa}$, whether the value obtained from $\mu$ DSC measurements or calculated by Clapeyron equation, are a little higher than Kang's investigation [46], our results are more consistent with Lee's work [29] and Yoon's study [45]. For $\left(\mathrm{CH}_{4}+\mathrm{CO}_{2}\right)$ binary hydrates system, the dissociation enthalpy is $57.23 \mathrm{~kJ} \cdot \mathrm{mol}^{-1}$ which is a little lower than the results investigated by Kwon [21] who performed their experiment using a PVT method and calculated the dissociation enthalpies from Clausius-Clapeyron equation. As for as the dissociation enthalpy of $\left(\mathrm{CH}_{4}+\mathrm{CO}_{2}+\mathrm{N}_{2}\right)$ ternary hydrates, there is no relevant data published in literature, but it is reasonable that the dissociation enthalpy of $57.37 \mathrm{~kJ} \cdot \mathrm{mol}^{-1}$ obtained here, because the mole fraction of $\mathrm{N}_{2}$ in hydrate phase are much lower and they basically have the same dissociation enthalpies with $\left(\mathrm{CH}_{4}+\mathrm{CO}_{2}\right)$ binary hydrates.

Table 7 The dissociation enthalpies of various gas hydrates in literature.

\begin{tabular}{|c|c|c|c|c|c|c|}
\hline $\begin{array}{c}\text { Guest } \\
\text { Molecule }\end{array}$ & $\begin{array}{c}\Delta H_{d} \\
\left(\mathrm{~kJ} \cdot \mathrm{mol}^{-1}\right)\end{array}$ & $\begin{array}{l}\text { Temperature } \\
\text { (K) }\end{array}$ & $\begin{array}{l}\text { Pressure } \\
(\mathrm{MPa})\end{array}$ & $\begin{array}{c}\text { Hydration } \\
\text { Number }\end{array}$ & Reference & Method \\
\hline \multirow[t]{4}{*}{$\mathrm{CH}_{4}$} & $54.44 \pm 1.45$ & $\begin{array}{c}280.60- \\
291.65\end{array}$ & $5.5-19.3$ & 6.00 & $\begin{array}{c}\text { Gupta et al. } \\
{[28]}\end{array}$ & DSC \\
\hline & $54.19 \pm 0.28$ & $85-270.0$ & $3.40 \pm 0.10$ & 6.00 & Handa [23] & Calorimeter \\
\hline & 56.9 & $273-286.0$ & $2.0-20.0$ & - & $\begin{array}{c}\text { Sloan et al. } \\
\text { [47] }\end{array}$ & $\begin{array}{l}\text { Clausius- } \\
\text { Clapeyron }\end{array}$ \\
\hline & $56.84 \pm 0.89$ & 273.15 & 0.1 & 6.38 & $\begin{array}{c}\text { Kang et al. } \\
{[46]}\end{array}$ & DSC \\
\hline
\end{tabular}




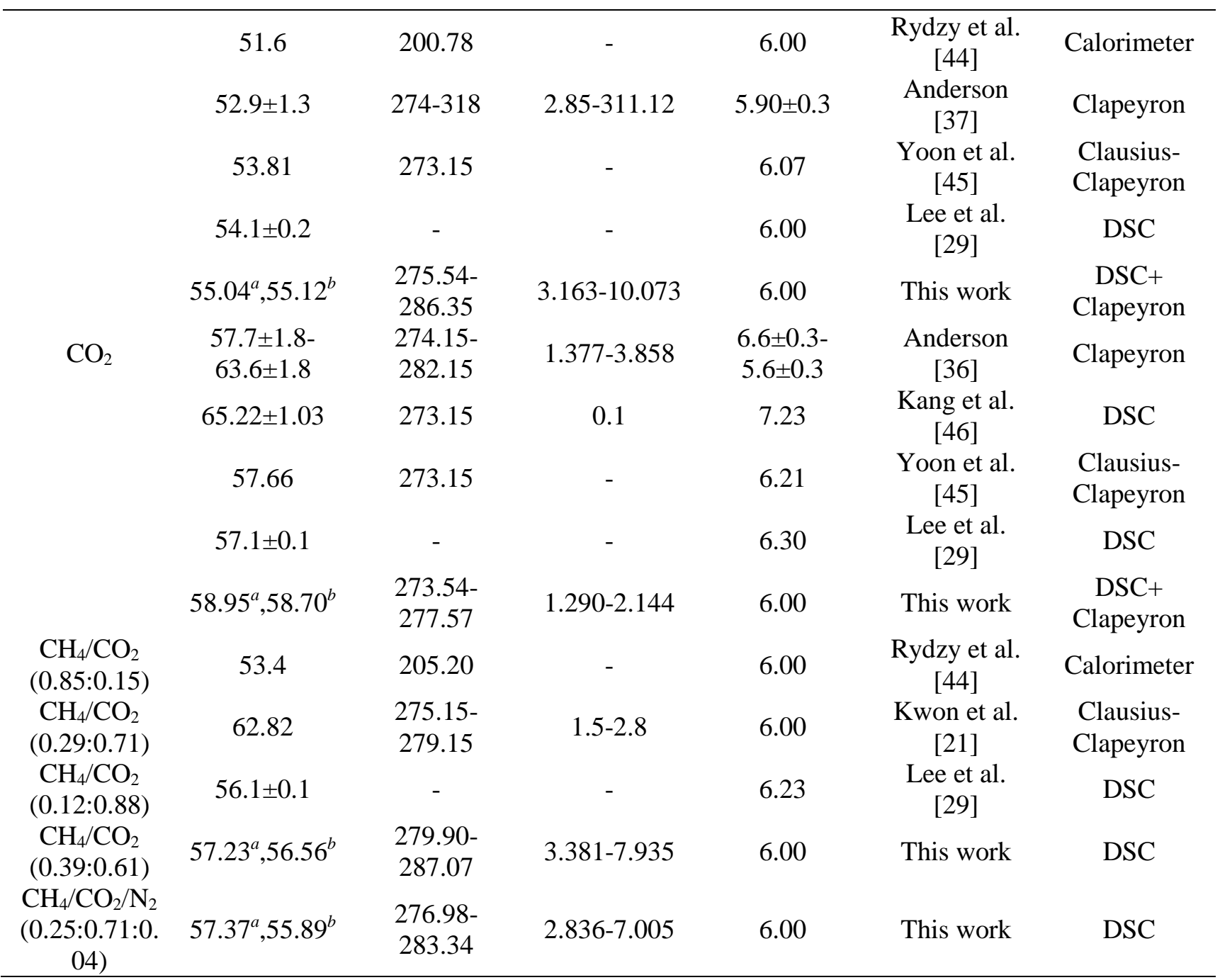

* $\mathrm{CH}_{4} / \mathrm{CO}_{2} / \mathrm{N}_{2}$ indicates the mole ratio of $\mathrm{CH}_{4}$ to $\mathrm{CO}_{2}$ to $\mathrm{N}_{2}$ in hydrate phase, $a$ is the DSC measurement value and $b$ is the calculation value by Clapeyron equation.

\subsection{The swapping process of $\mathrm{CH}_{4}$ hydrate by $\mathrm{CO}_{2}$ and $\left(\mathrm{CO}_{2}+\mathrm{N}_{2}\right)$}

In this work, in order to investigate if the $\mathrm{CH}_{4}$ hydrate would dissociate while the swapping reaction is proceeding, we used $\mu$-DSC apparatus to monitor the whole $\mathrm{CH}_{4}-\mathrm{CO}_{2} /\left(\mathrm{CO}_{2}+\mathrm{N}_{2}\right)$ swapping process in gas hydrates, because the $\mu$-DSC has a high resolution and any tiny heat changes caused by hydrate formation or dissociation can be detected. For an accurate experimental results of the $\mathrm{CH}_{4}-\mathrm{CO}_{2} /\left(\mathrm{CO}_{2}+\mathrm{N}_{2}\right)$ swapping, it should be keep the sample cell pressure no less than the equilibrium pressure at experimental temperature while releasing the free $\mathrm{CH}_{4}$ gas and blowing with $\mathrm{CO}_{2}$ or $\mathrm{M}_{3}$, make sure any possible $\mathrm{CH}_{4}$ hydrate dissociation during this process could be 
avoided. Figure 10 shows the heat flow changes in the process of $\mathrm{CH}_{4}$ release and swapping gas injection at $263.15 \mathrm{~K}$, it fluctuates and returns to the baseline quickly. Some researchers [15,48] reported the $\mathrm{CH}_{4}-\mathrm{CO}_{2}$ swapping process in gas hydrates undergoes a solid-liquid-solid transition and believed the $\mathrm{CH}_{4}$ hydrate would dissociate and reform. In this study, the swapping reaction process last for 24 hours and then increasing experimental temperature to dissociate the hydrate sample. Figure 11 shows the thermograms of $\mathrm{CH}_{4}-\mathrm{CO}_{2} / \mathrm{M}_{3}$ swapping at $263.15 \mathrm{~K}$, as we can see from that, there is no noticeable exothermic and endothermic peaks detected within the high resolution and sensitivity of $\mu$-DSC, it indicates that the swapping reaction occurs without significant hydrate dissociation or formation. This result is consistent with Ersland's [16] and Baldwin's [49] magnetic resonance imaging (MRI) experiments, in their investigation the free water phase was not detected during the $\mathrm{CH}_{4}-\mathrm{CO}_{2}$ swapping process. Figure 12 shows the dissociation thermograms of $\mathrm{CH}_{4}$ hydrate before swapping and the mixed hydrate after swapping, the endothermic peaks from the mixed hydrates have a significant shift with respect to the peak formed by pure $\mathrm{CH}_{4}$ hydrate dissociation, it indicates the hydrate composition has a dramatically change after swapping. 


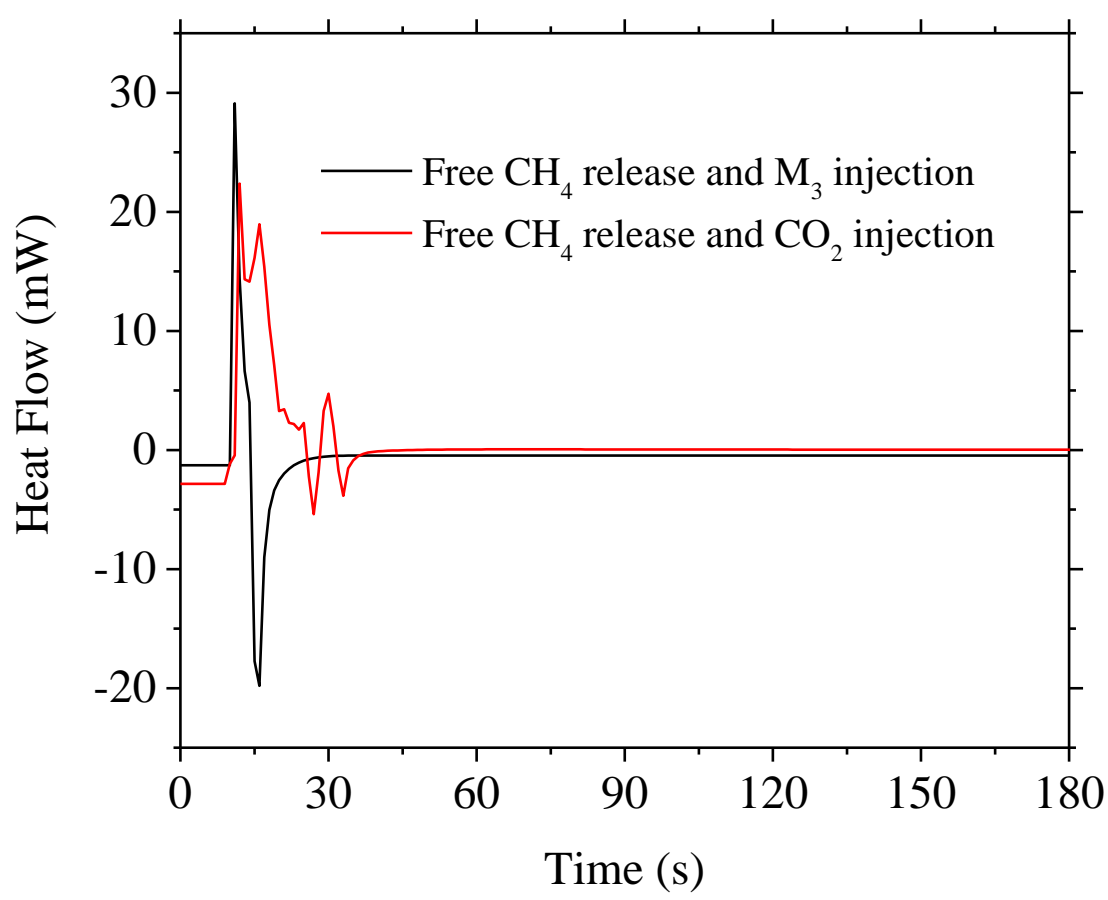

Figure 10. The changes of heat flow in the process of $\mathrm{CH}_{4}$ release and swapping gas injection at $263.15 \mathrm{~K}$.

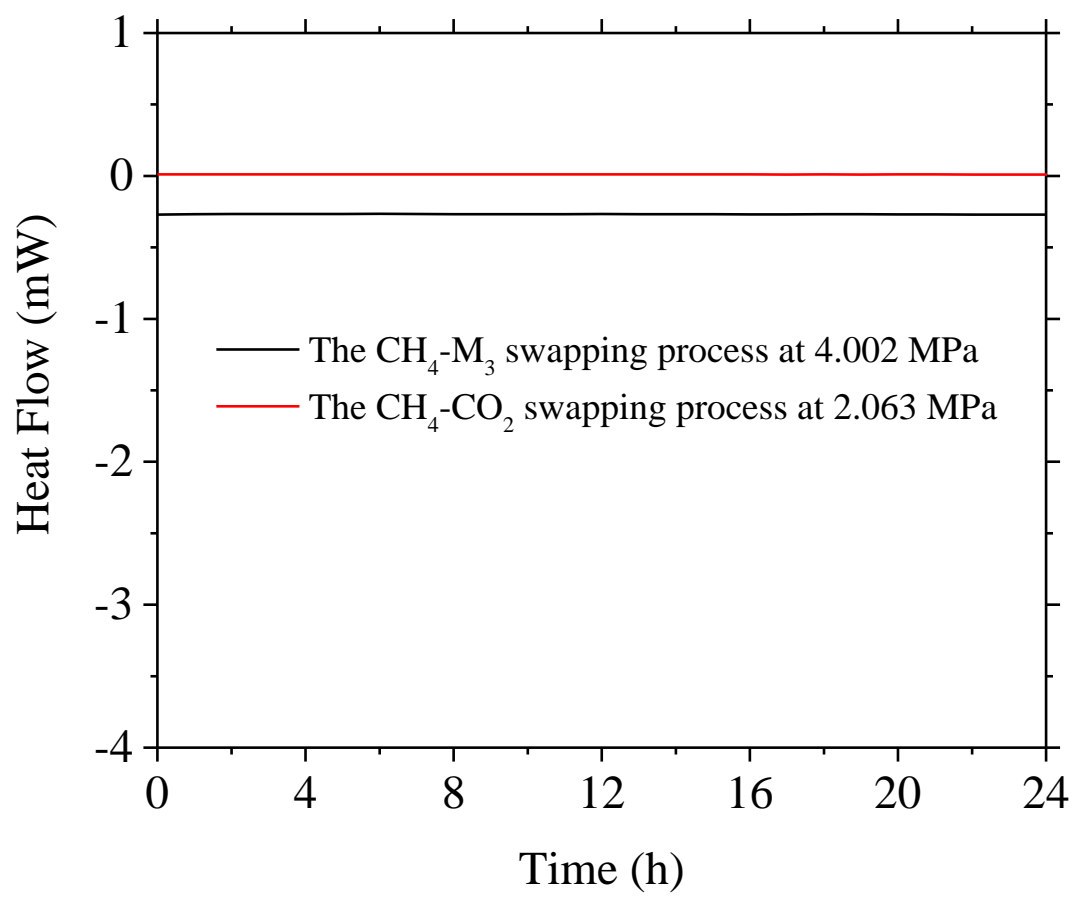

Figure 11. Thermograms of $\mathrm{CH}_{4}-\mathrm{CO}_{2} / \mathrm{M}_{3}$ swapping process at $263.15 \mathrm{~K}$. 


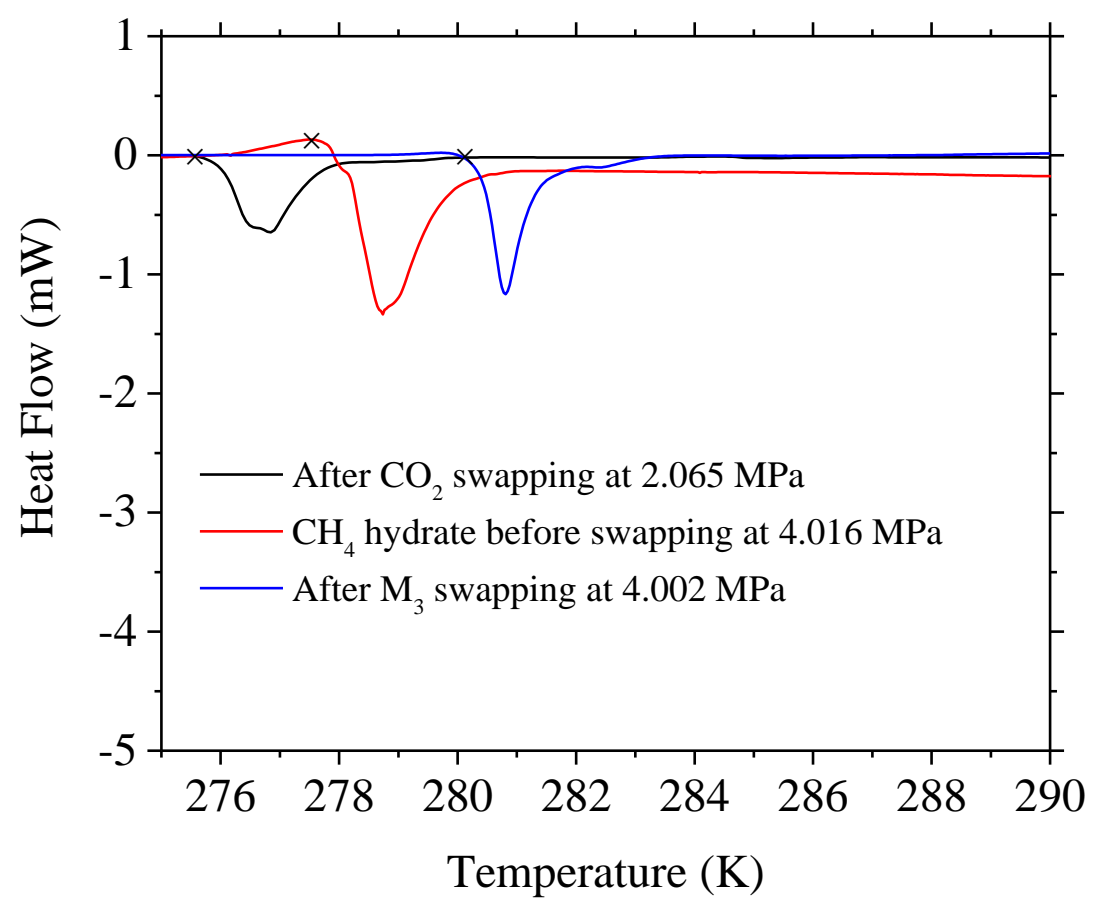

Figure 12. Dissociation thermograms of the pure $\mathrm{CH}_{4}$ hydrate before swapping and the mixed hydrates after $\mathrm{CO}_{2} / \mathrm{M}_{3}$ swapping.

\subsection{The estimation of the extent of swapping reaction in the $\mathrm{CH}_{4}$ gas hydrate}

The phase boundary and dissociation enthalpies of $\left(\mathrm{CH}_{4}+\mathrm{CO}_{2}\right)$ binary hydrates are located between that of the pure $\mathrm{CH}_{4}$ hydrate and that of the pure $\mathrm{CO}_{2}$ hydrate, hence it can provide an approximate estimation of the $\mathrm{CH}_{4}-\mathrm{CO}_{2}$ swapping reaction extent, because the composition of mixed hydrates after swapping can be calculated by fitting their dissociation equilibrium data with CSMGem model. As for as the mixed hydrates after $\left(\mathrm{CO}_{2}+\mathrm{N}_{2}\right)$ swapping, since the mole fraction of $\mathrm{N}_{2}$ in hydrate phase is much lower than that of $\mathrm{CO}_{2}$ and $\mathrm{CH}_{4}$, the extent of swapping can also be estimated like that. In this study, the dissociation equilibrium data of mixed hydrates after $\mathrm{CO}_{2} / \mathrm{M}_{3}$ swapping at different pressure was obtained through $\mu$-DSC measurements. As we can see from Figure 12, the measured dissociation equilibrium data of mixed hydrates after $\mathrm{CO}_{2}$ swapping have a 
good agreement with the phase boundary which formed by $\mathrm{M}_{1}$ binary hydrates. The composition of hydrate phase at different pressure are listed in Table 8 , it is found that only about $66 \%$ of $\mathrm{CH}_{4}$ in hydrate phase has been replaced by $\mathrm{CO}_{2}$ in the swapping reaction, since the $\mathrm{CO}_{2}$ molecules prefer to replace $\mathrm{CH}_{4}$ in large cages in hydrate, leaving $\mathrm{CH}_{4}$ in small cages almost intact. This result is in accord with Lee's research [12,17], they estimated the extent of $\mathrm{CH}_{4}-\mathrm{CO}_{2}$ swapping is approximately $67 \%$ from batch type reactions through thermodynamic equilibrium studies and ${ }^{13} \mathrm{C}$ NMR spectroscopic analysis. The measured dissociation equilibrium data of mixed hydrate after $\mathrm{M}_{3}$ swapping at different pressure match well with the hydrate phase boundary which formed by $\left(\mathrm{CO}_{2}\right.$ $60 \mathrm{~mol} \%+\mathrm{CH}_{4} 20 \mathrm{~mol} \%+\mathrm{N}_{2} 20 \mathrm{~mol} \%$ ) gas mixture, and it is estimated that about $85 \%$ of $\mathrm{CH}_{4}$ in hydrate phase has been replaced by $\mathrm{M}_{3}$ in the swapping reaction. This result is pretty close to Lee's [13] investigation of $\mathrm{CH}_{4}-\left(\mathrm{CO}_{2}+\mathrm{N}_{2}\right)$ exchange with microscopic experiments, they reported that the maximum swapping extent achieved is $84 \%$ for sI gas hydrate and confirmed that the preferential enclathration of $\mathrm{N}_{2}$ molecules in small $5^{12}$ cages of structure I hydrates improved the extent of the $\mathrm{CH}_{4}$ recovery by ${ }^{13} \mathrm{C}$ NMR and gas composition analyses [50,51]. In addition, the dissociation enthalpies of mixed hydrates after $\mathrm{CO}_{2} / \mathrm{M}_{3}$ swapping, which are measured by $\mu$-DSC and list in Table 8, are a little lower than that of the pure $\mathrm{CO}_{2}$ hydrate and higher than that of the $\mathrm{CH}_{4}$ hydrate. 


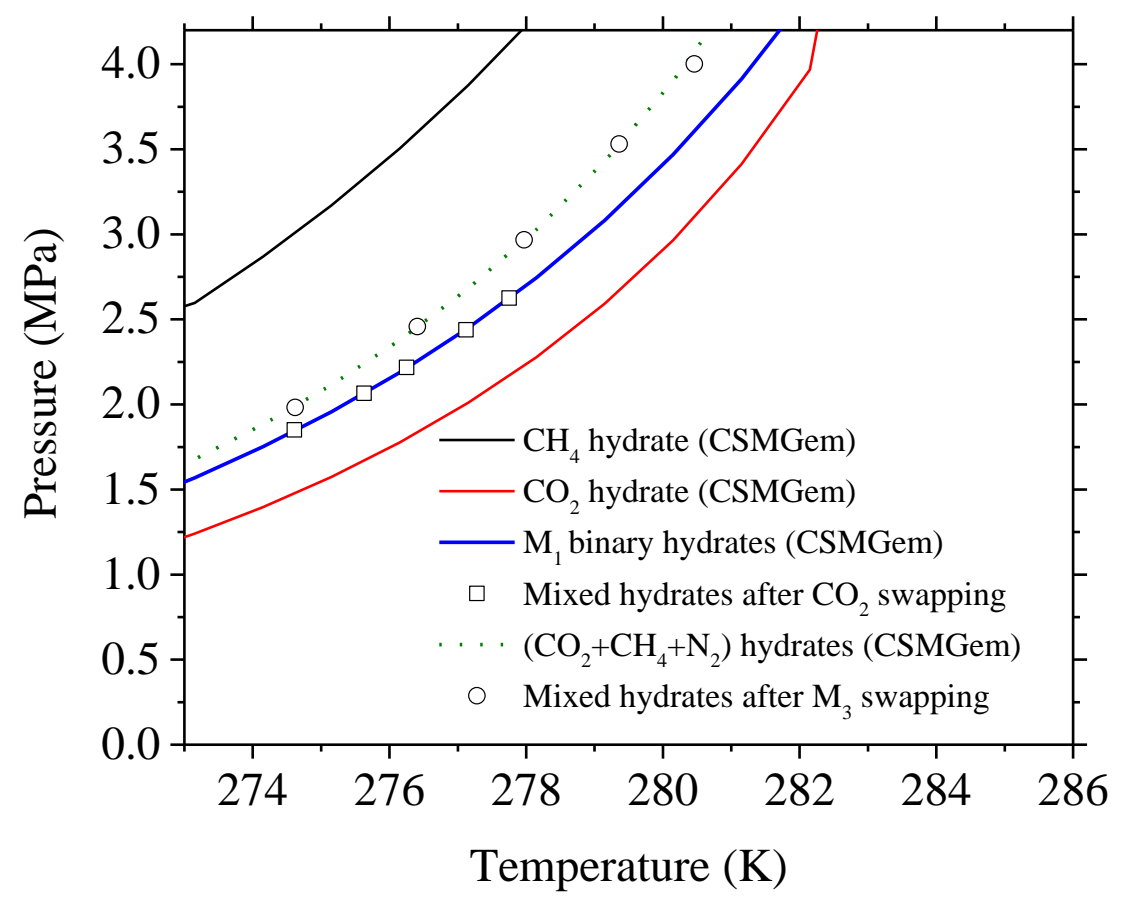

Figure 13. Dissociation equilibrium data of mixed hydrates after $\mathrm{CO}_{2}$ and $\mathrm{M}_{3}$ swapping at different pressure.

Table 8 The dissociation equilibrium data of mixed hydrates after $\mathrm{CO}_{2}$ and $\mathrm{M}_{3}$ swapping.

\begin{tabular}{|c|c|c|c|c|c|c|c|c|}
\hline$T_{\text {onset }}(\mathrm{K})$ & $P(\mathrm{MPa})$ & $m_{\mathrm{W}}(\mathrm{mg})$ & $\begin{array}{c}x_{\mathrm{I}} \\
\text { (wt } \%)\end{array}$ & $\begin{array}{c}x_{\mathrm{H}} \\
(\mathrm{wt} \%)\end{array}$ & $\begin{array}{c}C_{\mathrm{CH}_{4}}^{\mathrm{H}} \\
(\mathrm{mol} \%)\end{array}$ & $\begin{array}{c}C_{\mathrm{CO}_{2}}^{\mathrm{H}} \\
(\mathrm{mol} \%)\end{array}$ & $\begin{array}{c}C_{\mathrm{N}_{2}}^{\mathrm{H}} \\
(\mathrm{mol} \%)\end{array}$ & $\begin{array}{c}\Delta H_{d} \\
\left(\mathrm{~kJ} \cdot \mathrm{mol}^{-1}\right)\end{array}$ \\
\hline \multicolumn{9}{|c|}{ Mixed hydrates after $\mathrm{CO}_{2}$ swapping } \\
\hline 274.61 & 1.851 & 3.9 & 47.46 & 52.54 & 33.39 & 66.61 & - & 57.45 \\
\hline 275.63 & 2.065 & 3.8 & 67.63 & 32.37 & 33.76 & 66.24 & - & 57.43 \\
\hline 276.25 & 2.218 & 4.2 & 64.07 & 35.93 & 34.01 & 65.99 & - & 57.40 \\
\hline 277.12 & 2.439 & 4.2 & 57.96 & 42.04 & 34.36 & 65.64 & - & 57.38 \\
\hline 277.75 & 2.625 & 3.5 & 52.46 & 47.54 & 34.64 & 65.36 & - & 57.31 \\
\hline \multicolumn{9}{|c|}{ Mixed hydrates after $\mathrm{M}_{3}$ swapping } \\
\hline 274.62 & 1.982 & 3.5 & 57.26 & 42.74 & 14.97 & 81.99 & 3.04 & 57.83 \\
\hline 276.41 & 2.458 & 2.9 & 52.14 & 47.86 & 15.42 & 81.37 & 3.21 & 57.76 \\
\hline 277.97 & 2.968 & 2.8 & 49.14 & 50.86 & 15.86 & 80.76 & 3.38 & 57.56 \\
\hline 279.36 & 3.531 & 3.2 & 47.44 & 52.56 & 16.32 & 80.12 & 3.56 & 57.47 \\
\hline 280.31 & 4.002 & 2.2 & 52.46 & 47.54 & 16.69 & 79.60 & 3.71 & 57.35 \\
\hline
\end{tabular}

\section{Conclusion}


The $\mathrm{CH}_{4}-\mathrm{CO}_{2}$ swapping in naturally occurring gas hydrates is regarded as an attractive method of $\mathrm{CH}_{4}$ recovery and $\mathrm{CO}_{2}$ sequestration. In this study, a $\mu$-DSC apparatus was used to investigate the dissociation behavior of various gas hydrates, and it provided reliable measurements of hydrate dissociation equilibrium data and enthalpies for the pure and mixed gas hydrates. The $\mu$-DSC measured dissociation enthalpies of $\mathrm{CH}_{4}$ hydrate and $\mathrm{CO}_{2}$ hydrate are $55.04 \mathrm{~kJ} \cdot \mathrm{mol}^{-1}$ and 58.95 $\mathrm{kJ} \cdot \mathrm{mol}^{-1}$, respectively, which are very close to the calculation results by Clapeyron equation and literature values. The dissociation enthalpies of the $\left(\mathrm{CH}_{4}+\mathrm{CO}_{2}\right)$ binary hydrates and $\left(\mathrm{CH}_{4}+\mathrm{CO}_{2}+\mathrm{N}_{2}\right)$ ternary hydrates were between that of the pure $\mathrm{CH}_{4}$ hydrate and that of the pure $\mathrm{CO}_{2}$ hydrate, increasing with the mole fraction of $\mathrm{CO}_{2}$ in hydrate phase. It was found that there was no significant dissociation or formation phenomenon of hydrate occurring in the $\mathrm{CH}_{4}-\mathrm{CO}_{2} /\left(\mathrm{CO}_{2}+\mathrm{N}_{2}\right)$ swapping process by investigating the heat flow changes with the $\mu$-DSC apparatus. It indicates that most $\mathrm{CH}_{4}$ hydrate forms $\left(\mathrm{CH}_{4}+\mathrm{CO}_{2}\right)$ or $\left(\mathrm{CH}_{4}+\mathrm{CO}_{2}+\mathrm{N}_{2}\right)$ hydrate directly instead of dissociating into liquid water or ice first. The hydrate dissociation equilibrium data obtained from the endothermic thermograms of the mixed hydrates indicate that about $66 \%$ and $85 \%$ of $\mathrm{CH}_{4}$ is replaced after reaction with $\mathrm{CO}_{2}$ and $\left(\mathrm{CO}_{2}+\mathrm{N}_{2}\right)$, respectively.

\section{ACKNOWLEDGMENT}

The research leading to these results has received funding from the People Programme (Marie Curie Actions) of the European Union's Seventh Framework Programme (FP7/2007-2013) under REA grant agreement $n^{\circ} 609405$ (COFUNDPostdocDTU).

\section{References}

[1] E.D. Sloan, C.A. Koh, Clathrate Hydrates of Natural Gases, third ed., CRC Press, Taylor \& Francis Group, New York, 2008. 
[2] S. Circone, S.H. Kirby, L.A. Stern, J. Phys. Chem. B 109 (2005) 9468-9475.

[3] W.B. Durham, S.H. Kirby, L.A. Stern, W. Zhang, J. Geophys. Res. Solid Earth (1978-2012) 108 (2003) 1-11.

[4] J.S. Tse, M.L. Klein, I.R. McDonald, J. Phys. Chem. 87 (1983) 4198-4203.

[5] Y.F. Makogon, J. Nat. Gas Sci. Eng. 2 (2010) 49-59.

[6] R. Boswell, T.S. Collett, Energy Environ. Sci. 4 (2011) 1206-1215.

[7] T. Collett, J.J. Bahk, R. Baker, R. Boswell, D. Divins, M. Frye, D. Goldberg, J. Husebø, C. Koh, M. Malone, M. Morell, G. Myers, C. Shipp, M. Torres, J. Chem. Eng. Data 60 (2015) 319-329.

[8] R. Boswell, T. Collett, M. Frye, W. Shedd, D. McConnell, D. Shelander, Marine Petrol. Geol. 34 (2012) 4-30.

[9] T.S. Collett, R. Boswell, Marine Petrol. Geol. 34 (2011) 1-3.

[10] J.B. Klauda, S.I. Sandler, Energy Fuels 19 (2005) 459-470.

[11] K. Ohgaki, K. Takano, H. Sangawa, T. Matsubara, S. Nakano, J. Chem. Eng. Jpn. 29 (1996) 478-483.

[12] H. Lee, Y. Seo, Y. T. Seo, I. L. Moudrakovski, J. A. Ripmeester, Angew. Chem. Int. Ed. 42 (2003) 5048-5051

[13] Y. Park, D.Y. Kim, J.W. Lee, D.G. Huh, K.P. Park., J. Lee, H. Lee, Proc. Natl. Acad. Soc. USA. 103 (2006) 12690-12694.

[14] D.Y. Koh, H. Kang, D.O. Kim, J. Park, M. Cha, H. Lee, Chem Sus Chem 5 (2012) 1443-1448.

[15] J.M. Schicks, M. Luzi, B. Beeskow-Strauch, J. Phys. Chem. A 115 (2011) 13324-13331. 
[16] G. Ersland, J. Husebф, A. Graue, B.A. Baldwin, J. Howard, J. Stevens, Chem. Eng. J. 158 (2010) 25-31.

[17] S. Lee, S. Park, Y. Lee, Y. Seo, Chem. Eng. J. 225 (2013) 636-640.

[18] Q. Yuan, C.Y. Sun, X. Yang, P.C. Ma, Z.W. Ma, B. Liu, Q.L. Ma, L.Y. Yang, G.J. Chen, Energy 40 (2012) 47-58.

[19] P. Dornan, S. Alavi, T.K. Woo, J. Chem. Phys. 127 (2007) 124510-124518.

[20] D.A. Gunn, L.M. Nelder, C.A. Rochelle, K. Bateman, P.D. Jackson, M.A. Lovell, P.R.N. Hobbs, D. Long, J.G. Rees, P. Schultheiss, J. Roberts, T. Francis, Terra Nova 14 (2002) 443-451.

[21] T.H. Kwon, T.J. Kneafsey, E.V.L. Rees, J. Phys. Chem. B 115 (2011) 8169-8175.

[22] Y.P. Handa, R.E. Hawkins, J.J. Murray, J. Chem. Thermodyn. 16 (1984) 623-632.

[23] Y.P. Handa, J. Chem. Thermodyn. 18 (1986) 915-921.

[24] Y.P. Handa, Ind. Eng. Chem. Res. 27 (1988) 872-874.

[25] D. Dalmazzone, M. Kharrat, V. Lachet, B. Fouconnier, D. Clausse, J. Therm. Anal. Calorim. 70 (2002) 493-505.

[26] M. Kharrat, D. Dalmazzone, J. Chem. Thermodynamics 35 (2003) 1489-1505.

[27] R. Nakagawa, A. Hachikubo, H. Shoji, in: 6th Proceedings of International Conference on Gas Hydrates, Vancouver, British Columbia, Canada, 2008.

[28] A. Gupta, J. Lachance, E. D. Sloan Jr., C. A. Koh, Chem. Eng. Sci. 63 (2008) 5848-5853.

[29] S. Lee, Y. Lee, J. Lee, H. Lee, Y. Seo, Environ. Sci. Technol. 47 (2013) 13184-13190. 
[30] V.A. Kamath, Study of heat transfer characteristics during dissociation of gas hydrates in porous media, Ph.D. Thesis, University of Pittsburgh, Pittsburgh, PA, USA, 1984.

[31] Q. Nasir, K.K. Lau, B. Lal, International Journal of Chemical, Molecular, Nuclear, Materials and Metallurgical Engineering 8 (2014) 840-843.

[32] S. Circone, L.A. Stern, S.H. Kirby, W.B. Durham, B.C. Chakoumakos, C.J. Rawn, A.J. Rondinone, Y. Ishii. J. Phys. Chem. B, 107 (2003) 5529-5539.

[33] R.W. Henning, A.J. Schultz, V. Thieu, Y. Halpern, J. Phys. Chem. A 104 (2000) 5066-5071.

[34] K.A. Udachin, C.I. Ratcliffe, J.A. Ripmeester, J. Phys. Chem. B 105 (2001) 4200-4204.

[35] J.H. Van der Waals, J.C. Platteeuw, Nature 183 (1959) 462.

[36] G.K. Anderson, J. Chem. Thermodyn. 35 (2003) 1171-1183.

[37] G.K. Anderson, J. Chem. Thermodyn. 36 (2004) 1119-1127.

[38] S. Adisasmito, R.J. Frank, E.D. Sloan, J. Chem. Eng. Data 36 (1991) 68-71.

[39] J.H. van der Waals, J.C. Platteeuw, Adv. Chem. Phys. 2 (1959) 1-57.

[40] P. Babu, T. Yang, H.P. Veluswamy, R. Kumar, P. Linga, J. Chem. Thermodyn. 61 (2013) 5863.

[41] K.M. Sabil, G.J. Witkamp, C.J. Petersa, Fluid Phase Equilib. 290 (2010) 109-114.

[42] P. Babu, P. Paricaud, P. Linga, Fluid Phase Equilib. 413 (2016) 80-85.

[43] W. Lin, A. Delahaye, L. Fournaison, Fluid Phase Equilib. 264 (2008) 220-227.

[44] M.B. Rydzy, J.M. Schicks, R. Naumann, J. Erzinger, J. Phys. Chem. B 111 (2007) 9539-9545. 
[45] J.H. Yoon, Y. Yamamoto, T. Komai, H. Haneda, Ind. Eng. Chem. Res. 42 (2003) 1111-1114.

[46] S.P. Kang, H. Lee, B.J. Ryu, J. Chem. Thermodyn. 33 (2001) 513-521.

[47] E.D. Sloan, F. Fleyfel, Fluid Phase Equilib. 76 (1992) 123-140.

[48] M. Ota, K. Morohashi, Y. Abe, M. Watanabe, R.L. Smith, J. H. Inomata, Energy Convers. Manage. 46 (2005) 1680-1691.

[49] B.A. Baldwin, J. Stevens, J.J. Howard, A. Graue, B. Kvamme, E. Aspenes, G. Ersland, J. Husebø, D.R. Zornes, Mag. Reson. Imag. 27 (2009) 720-726.

[50] Y. Lee, Y. Kim, J. Lee, H. Lee, Y. Seo, Applied Energy 150 (2015) 120-127.

[51] M. Cha, K. Shin, H. Lee, I.L. Moudrakovski, J.A. Ripmeester, Y. Seo, Environ. Sci. Technol. 49 (2015) 1964-1971. 